\title{
Repensando os Desafios de Ulisses a Fausto: A Saúde, o Indivíduo e a História
}

\author{
Rethinking the Challenges of Ulysses and Faust: Health, The Individual \\ and History
}

Djalma A. de Melo-Filho'

MELO-FILHO, D. A. Rethinking the Challenges of Ulysses and Faust: Health, The Individual and History. Cad. Saúde Públ., Rio de Janeiro, 11 (1): 05-33, Jan/Mar, 1995.

Concentrating on two historical synecdoches, Ulysses and Faust, this article takes up the etymology of the Latin term salute as a unit lying somewhere between "existential needs" and "especially human needs", leading to the challenge of satisfying the need for "conservation of life" and at the same time to "surpass it, go beyond it". Both meanings are present in Ulysses' attitude of not succumbing to the siren's melody and in Faust's desire to rise above everyday life. Some aspects of the Marxist conception of the philosophy of history and Althusser's Structuralist Marxism are criticized. Also, in light of Marxist-Hellerian theory, the article analyzes the hypothesis that the target of the final reports of the VIII National Health Conference was "particular man" and not the individual, since health is treated only as "an existential need", and does not envisage the generic human. As a theoretical challenge, the text, in search of the unfolding individual, finally recommends the construction of "epistemological sutures" between nature and society, everyday life and universality, and the young and old Marx.

Key words: History and Health; Individual and Health; Society and Health; Human Needs and Health

\section{O RECURSO À IMAGINAÇÃO: ULISSES E A CONDIÇÃO HUMANA}

A fim de que se possa responder, ou pelo menos bosquejar, qual seria o desafio contemporâneo da Saúde Pública, convém, de início, solicitar a permissão para se utilizarem duas sinédoques, advindas da história, a expressas nas figuras de Ulisses de Homero e Fausto de Goethe. O uso de tal recurso, em vez da metáfora, além de servir de balizamento para a reflexão sobre o tema proposto, mantém o distanciamento necessário, a não a identidade, entre a consciência a aquilo de que se tem consciência, afastando-se, assim, do idealis-

\footnotetext{
${ }^{1}$ Núcleo de Estudos em Saúde Coletiva, Centro de Pesquisas Aggeu Magalhães, Fundação Oswaldo Cruz. Rua dos Coelhos, 450, Antigo Hospital Pedro II, $1^{\circ}$ andar, Recife, PE, 50070-550, Brasil.
}

mo imanentista. Lembra-se, ainda, que tanto a tradição empirista como a racionalista têm preconceitos em fazer uso da referida faculdade: a primeira a considera "destroços de percepção" e a segunda a chama de "falsos juízos". Deve-se a Husserl a reabilitação da imaginação da sarjeta em que foi posta pelo positivismo. Tanto ele como Sartre (1973) dizem que o "aparecer em imagem" nem é juízo, nem percepção, criticando as teorias que o concebem como uma "figura de desrazão" ou um "produto do hábito".

Ulisses a Fausto não existem de fato, no entanto subsistem em imagem, isto é, são as mesmas pessoas (identidade de essência), mas em diferentes planos de existência. Sartre (1973: 120) ainda esclarece que "Não há, não poderia haver imagens na consciência. Mas a imagem é um certo tipo de consciência. A imagem é um ato a não uma coisa. A imagem é consciência de alguma coisa”. Benjamin (1985: 155) conclui: 
"A vera imagem do passado passa zumbindo. Só enquanto imagem que fulgura, para nunca mais ser vista, exatamente no instante de sua recognoscibilidade é possível fixar o passado".

Ante o consentimento, tentase, agora, perscrutar o problema formulado. Numa primeira aproximação, desafiar significa "propor duelo ou combate a" (Ferreira, 1975), implicando, conseqüentemente, a convivência com o perigo - o perigo do filosofar (Heller, 1983a). A condenação à morte de Sócrates ou de Bruno; a prisão de Diderot; o exílio de Aristóteles, ou de Descartes, ou de Marx constituem aspectos extremados desse risco, mas não o exaurem. "As perguntas pueris", segundo Heller (1983a: 23), "contêm dois momentos: a ausência de preconceitos, o questionamento dos conceitos prontos a acabados, pot um lado; e, por outro, a sede de saber, de conhecimento". $O$ risco final de toda reflexão teórica é considerar apenas o segundo momento, desatendendo-se o primeiro. Aos que costumam cair nessa tentação, Mefistófeles avisa: "Meu amigo, toda teoria é seca, e a preciosa árvore da vida é florida" (Goethe, 1984).

Numa segunda perspectiva, complementar da primeira, desafiar significa: "instigar", "incitar", "excitar", "estimular", "provocar" (Ferreira, 1975), verbos que exprimem a idéia de passagem da inércia para o movimento, negando, enfim, uma determinada situação na qual se encontra um corpo. É conveniente, ainda, assinalar que o conjunto dos significados evoca a imagem de um "movimento perigoso", semeIhante àquele, descrito na Odisséia, vivenciado por Ulisses.

A partir da Dialética do Iluminismo de Adorno a Horkheimer, Matos (1993) assere que a atitude de Ulisses, narrada no canto XII da epopéia, de ordenar aos seus companheiros que tapassem os ouvidos com cera para impedi-los de ouvir o chamado das sereias, inaugura a passagem da natureza para a cultura. Vencer o desafio pressupõe afastar-se do perigo.

Simultaneamente, a reminiscência também retira a morte do reino exclusivo da natureza, impingindo-lhe as mediações culturais. Ulisses, preso ao mastro do navio, percebe o canto, porém não sucumbe, pois considera - poderia não considerar - os alertas da feiticeira Circe: "Elas [as sereias] se encontram num prado; ao redor se lhe vêem muitos ossos de corpos de homens desfeitos, nos quais se engrouvinha a epiderme. Passa de largo; mas tapa os ouvidos de todos os sócios com cera doce amolgada, porque nenhum deles o canto possa escutar" (Homero, s/d). A "barreira cerácea" anuncia o advento da cultura que passa, a partir daí, a intervir nos processos, até então exclusivamente naturais, de vida-morte e saúde-doença.

Heller (1993: 15) assevera que "A soleira para a humanidade é cruzada no momento em que as normas substituem os instintos". Duas delas - recusar o lótus e determinar que os marinheiros naveguem com os ouvidos tapados -, ambas de caráter sanitário, no sentido etimológico do termo [saúde provém do latim salute, que significa "conservação da vida", "salvação"] (Ferreira, 1975), permitem que Ulisses atravesse a aludida soleira.

Entretanto, é necessário reconhecer que a ruptura entre mythos a logos ainda está incompleta, como revela esta fala de Ulisses: "Caros amigos, não basta que um só, ou que dois fiquem cientes do que respeita ao destino que Circe preclara me disse. Não; quero tudo contar-vos, porque procuremos a morte conscientemente ou possamos fugir do Destino funesto". Embora esteja nas mãos do protagonista a decisão de se vergar (ou não) ante o canto mavioso das sereias, o diagnóstico da situação provém do mythos e não do logos. "O tema da 'lição", comenta Heller (1993: 17), "está sempre presente nos mitos. Uma vez que a gênese legitima a ordem existente enquanto ordem de existência, o mito nos fala do que devemos fazer e do que devemos evitar, do que devemos temer e do que devemos esperar".

As duas normas seguidas por Ulisses estabelecem a condição humana, caracterizada, segundo Marx (apud Markus, 1974b), pela socialidade, consciência, trabalho, liberdade e universalidade. São esses atributos, segundo Heller (1983b: 33), "que caracterizam a humanidade desde a sua formação, opondo-a ao mundo dos animais, a daí estas serem as potencialidades do homem. O processo de realização destas potencialidades é própria história humana".

O trabalho e a socialidade, expressos na atitude de Ulisses: "Uma rodela de cera cortei com meu bronze afiado, em pedacinhos, $e$ pusme a amassá-los nos dedos possantes" 
(Homero, s/d), representam a possibilidade do domínio sobre as forças da natureza. A recusa à ilusão, quando não ingere o lótus, mantém-lhe a consciência: "Só Ulisses é sujeito porque conserva a memória, a possibilidade de manter a tradição, vale dizer, a cultura" (Matos, 1993: 146). Resistindo à tentação do retomo ao passado (natureza), simbolizado pelo canto das sereias, Ulisses conquista a liberdade: Elas "Prometiam plenitude e felicidade, mas ameaçam a autonomia do sujeito" (Matos, 1993: 146).

Todavia, a hermenêutica não estaria completa, caso não se considere a outra face do episódio: os companheiros de Ulisses evitam a morte iminente, todavia recusam a beleza do canto, negada, também, a uma grande parte da humanidade. Comentando esse fato, Matos (1993: 147) escreve que "desde o início do pensamento ocidental, a luta pela autoconservação $e$ autonomia se vinculou ao sacrifício, à repressão, à renúncia”.

O devir da humanidade liga-se à atitude perigosa de "conservar a vida" (salute): Asclépio, ao ressuscitar vários mortos, é fulminado por Zeus e, ao roubar o fogo sagrado dos deuses a doá-lo aos homens, Prometeu é condenado a ter seu fígado bicado por uma ave. Humanidade também significa "benevolência", "clemência" e “compaixão" (Ferreira, 1975), características demonstradas por Antígona ao exigir de Creonte que lhe conceda o direito de sepultar dignamente o irmão Polinice.

$O$ fato de Ulisses controlar os instintos faz dele um ser humano, mas não, necessariamente, um indivíduo, no sentido helleriano do termo: o ente que transcende a particularidade. Marx, citado por Heller (1991), distingue o homem como pura existência e o indivíduo, isto é, o homem que desenvolve as forças da essência: "o individuo já não quer conservar-se 'a todo custo' e "de qualquer modo"'.

Mas Ulisses não só "conserva a vida" (salute), ele continua desejando o canto. A verdade, revelada por Circe, garante-the o bem (vida), agora só lhe resta apreender o belo.

Não se pode esquecer de que o belo, nesse caso, representa os tempos idos, o corte do cordão umbilical com a natureza. Sendo impossível a satisfação do desejo, Ulisses torna-se melan- cólico, restando-lhe o retorno a Ítaca, mas Ítaca, como frisa Matos (1993), já não é a mesma.

E então, como resolver a tensão entre a impossibilidade do retorno ao passado (representado pelo canto das sereias/natureza) e a satisfação do desejo de continuar ouvindo o canto (passado)? Em outra formulação: como "conservar a vida" (salute) a buscar ao mesmo tempo a beleza do canto, sabendo-se que "o paradoxo éticalestética consiste em o Belo estar mais próximo de Narciso a da Morte do que de Eros a da Sociabilidade” (Mann apud Kehl, s/d: 48). “... a filosofia, diz Heller (1983a: 25), é uma utopia racional sobre a tensão entre ser $e$ dever-ser na qual o ser é construído a partir do dever-ser, do Bem, do Verdadeiro e - embora nem sempre - do Belo".

Ulisses, não resolvendo o impasse, põe para humanidade o seguinte desafio: como resguardar a existência, sem abdicar da essência (no sentido marxista do termo)?

Como minimizar a distância que separa o desenvolvimento humano-genérico a as possibilidades de desenvolvimento dos indivíduos? Sabe-se que essa cisão histórica não é uniforme em todas as épocas e em todas as classes sociais. Na maior parte da história humana, a dissensão constitui-se num grande abismo, mas há exceções, onde a cesura praticamente desapareceu: Atenas nos séculos VI e V a.C. e Florença nos séculos XIII a XIV d.C. (Heller, 1989; 1991).

Ambas as cidades-estados têm a democracia como regime de governo, mas o desenvolvimento de cada uma delas se dá em condições econômicas, sociais a políticas diversas. Atenas vive a época das comunidades naturais; Florença começa a ver a aurora do capitalismo, com a desintegração das mesmas comunidades e o surgimento da sociedade propriamente dita, conforme Marx demarca nos Grundrisse.

\section{A SAUDAÇÃO DA ÁGORA: DEMOCRACIA!}

Como o desafio, "posto por Ulisses", é enfrentado na pólis grega? De inicio, recorde-se a identidade entre salute e democracia. Alcméon de Crotona, líder da escola médica de influência pitagórica, diz que o corpo humano é semelhante a um Estado onde a saúde é representada pela 
isonomía das forças em oposição, e a doença corresponde a monarchía de um dos quartro elementos (ar, terra, fogo a água). Empédocles, que aparentemente funda a escola médica siciliana, combinando o ser imóvel, homogêneo e eterno de Parmênides e o ser em movimento de Heráclito, defende a demókratía que, segundo ele, não só orienta o corpo, mas também todo o universo (Pessanha, 1978).

Os pré-socráticos, primeiros filósofos gregos, rompem com o mágico-sobrenatural para explicar a gênese da vida. A teoria humoral recusa a ontologia da doença a integra, ao mesmo tempo, natureza e paixões humanas: o amor (philia) favorece a união dos quatro elementos, enquanto o ódio (neikos) os separa: "Quando os elementos se misturam produz-se a vida; quando se separam ocorre a morte" (Tamayo, 1988: 109).

Hipócrates e seus discípulos da Escola de Cós, adotando os cânones já esboçados pelos pré-socráticos, "empreendiam o esforço de favorecer o esforço curativo natural", quando havia desequilíbrio, isto é, "alterações naturais que faziam o homem sofrer" (Gonçalves, s/d; Testa, 1992). Mas nem todos os homens, somente os cidadãos. A um outro tipo de "médico" é destinada a tarefa de resgatar a funcionalidade dos corpos dos trabalhadores livres e escravos (Gonçalves, s/d). A existência destes últimos é louvada tanto na academia platônica como no liceu aristotélico. Agora, em vez do mythos (Circe) é o logos que justifica a "surdez" dos escravos para o Belo.

Para "conservar a vida", os gregos não se confrontam com as "sereias"; descobrem urn ponto de equilíbrio entre a cultura e a natureza: a atividade social, a contemplação, o divertimento (cultivo das faculdades físicas a mentais) ocupam lugar central em sua vida cotidiana (Heller, 1989). Neste caso, o navio, agora a uma "distância adequada" das "sereias", possibilita que Ulisses desenvolva as potencialidades da essência humana, todavia, não se pode esquecer, aos marinheiros (tom os ouvidos tapados) continua a ser negado o canto.

Heller (1983c: 12) afirma que apesar das vicissitudes, referidas anteriormente, é em Atenas, na primeira metade da era de Péricles, onde passam a existir as "circunstâncias que permitiram uma margem mínima entre as possibilidades evolutivas da sociedade a as do indivíduo particular".

Com a superação de sua "infância normal", a humanidade (Ulisses), haja vista o desejo insatisfeito, novamente se torna melancólica. Por isso, Marx (1991c) escreve na Introdução à Critica da Economia Política:

"Um homem não pole voltar a set criança sem cair na puerilidade. Mas não ache prazer na inocência da criança e, tendo alcançado um nível superior, não deve aspirar ele próprio a reproduzir sue verdade? Em todas as épocas, o sea próprio caráter não revive na verdade natural da natureza infantil? Por que então a infância histórica da humanidade, precisamente naquilo em que atingiu sea mais belo florescimento, pot que esta etapa pats sempre perdida não há de exercer um eterno encanto?" (Marx, 1991c, 25)

Ao continuar desejando o "para-sempreperdido", Ulisses mantém-se melancólico. Entretanto, é necessário reconhecer: "Não se pode lembrar do que ainda não aconteceu, nem ter propósitos com relação ao passado. Mesmo assim, constitui a mais pura expressão de nossa historicidade o fato de que não nos satisfazem tais limitações: queremos saber nosso futuro e alterar nosso passado" (Heller, 1993: 53). Sendo assim, a melancolia de Ulisses, enquanto sinédoque, transforma-se, durante o Renascimento, na angústia de Fausto.

\section{A SAÚDE NO JARDIM DAS VOLÚPIAS}

É, pois, na aurora do capitalismo, que começa a ser desfeita a contraditória harmonia entre o indivíduo e a comunidade. É criada uma nova situação: as forças produtivas capitalistas e as relações sociais burguesas emergem das contradições do feudalismo e exigem um atuar, um sentir e um pensar diferentes daqueles da Antiguidade Clássica. O sumo-bem, que em Atenas é a felicidade, agora passa a ser a liberdade (Heller, 1980). Assinala-se, entretanto, que os ideais do mundo antigo, aliados aos de certas tendências do cristianismo, também influenciam a ideologia renascentista, formada pela simbiose entre Sócrates e Jesus. 
A concepção de saúde na Utopia de Morus (s/d), antes de ser somente a ausência de doença, consiste numa espécie de prazer.

"Os utopianos distinguem diversas espécies de prazeres verdadeiros: uns se relacionam com o corpo, outros com a alma. (...) Eles dividem em duas espécies as voluptuosidades do corpo: A primeira espécie compreende todas as volúpias que exercem sobre os sentidos uma impressão atual, manifesta, a cuja causa é o restabelecimento dos órgãos consumidos pelo calor interno. (...) A segunda espécie de volúpia sensual consiste no equilíbrio estável e perfeito de todas as partes do corpo, isto é, numa saúde isenta de mal-estar. Com efeito, o homem que não é afetado pela dor, experimenta em si um certo sentimento de bem-estar, mesmo que nenhum objeto exterior agite agradavelmente os seus órgãos. É verdade que esta espécie de volúpia não afeta nem atordoa os sentidos, como por exemplo os prazeres da mesa; apesar disso, muitos a colocam em primeiro lugar, a quase todos os utopianos declaram que ela é a base e o fundamento da verdadeira felicidade.

Porque, dizem, só uma saúde perfeita torna a condição da vida humana tranqüila e apetecível; sem saúde, não há voluptuosidade possível; sem ela, a própria ausência da dor não é um bem, é a insensibilidade do cadáver" (Morus, s/d: 109-110).

Em A Cidade do Sol de Campanella (s/d: 41), outra utopia renascentista, "cada indivíduo não trabalha mais do que quatro horas por dia, consagrando o restante ao estudo, à leitura, às discussões científicas, ao escrever, ao conservar, ao pensar, enfim, a toda espécie de exercícios agradáveis e úteis, tanto ao corpo como à mente".

\section{DA PARTICULARIDADE AO HUMANO-GENÉRICO: A SAÚDE COMO AUFHEBUNG}

Novamente na Idade Moderna, o ser humano se vê inquieto diante da simples "conservação da vida”. Fausto também vive uma situação-limite semelhante à de Ulisses. Diz ele a Mefistófeles: "Quaisquer que sejam as ves- tes que me cobrirem, não sentirei menos a miséria da existência humana. Estou velho demais para aproveitar e muito moço para não ter desejos. Que pode o mundo me oferecer de bom? (...) Por isso é que a vida me é um fardo, por isso desejo a morte a abomino a existência" (Goethe, 1984).

$\mathrm{O}$ anseio pelo retomo ao passado (canto das sereias) é projetado para o futuro: talvez o Belo também possa ser encontrado lá. Revele-se, pois, a aspiração faustiana: "Precipitemo-nos no murmúrio do tempo, nas vagas agitadas do destino! E que, depois, a dor e a alegria, o êxito e o infortúnio, acompanhem, como puderem. É preciso que, de agora em diante, o homem se empenhe sem descanso" (Goethe, 1984). Mefistófeles, "o espírito que nega sempre", propõe-lhe um pacto e, em troca, mostra-lhe a história: "Não vos está designado limite algum, fim algum. Se vos agradar provar um pouco de tudo, apoderar-se do que aparecer, fazei como quiserdes. Vamos, segui-me a não sejais tímido!" (Goethe, 1984).

É sabido, como frisa Heller (1989: 75), que o alvorecer do capitalismo cria a possibilidade de desenvolvimento do processo de construção do indivíduo, mas "essa mesma sociedade, ao subsumir o indivíduo sob sua classe, ao submetê-lo às leis econômicas como se essas fossem leis naturais, aboliu aquela possibilidade e fez dos indivíduos livres nada mais que escravos da alienação, até o ponto em que de facto os indivíduos se viram colocados num nível inferior àquele dos indivíduos de épocas anteriores".

O desejo de Fausto pela universalidade fá-lo "esquecer" a própria particularidade, entendida, aqui, como vida cotidiana. Veja-se, por exemplo, o que Mefistófeles diz dele ao Senhor: "Ele [Fausto] vos serve de um modo bem estranho. Nada há de terreno naquele louco, nem mesmo beber a comer" (Goethe, 1984). Reconhece-se, porém, que "A vida cotidiana é a vida de todo homem, qualquer que seja seu posto na divisão do trabalho intelectual e físico. Ninguém consegue identificar-se com sua atividade humano-genérica a ponto de poder desligar-se inteiramente da cotidianidade" (Heller, 1989: 17).

O "esquecimento" também põe em risco a própria "conservação da vida", a própria condição humana: ele "não consegue enfrentar a velhice 
ou a morte, nem aceita o conhecimento limitado" (Heller, 1993), características da referida condição. "A morte", segundo Marx (1991b: 170), "aparece como uma dura vitória do gênero sobre o indivíduo e parece contradizer a unidade de ambos; mas o indivíduo determinado é apenas um ser genérico determinado e, enquanto tal, mortal".

Concluídas as pertinentes digressões, propõe-se, agora, um primeiro arremate teórico. A atitude, que mais se avulta em Ulisses, como também aquela de Fausto em fazer urna excursão pela história estão intimamente ligadas à etimologia da palavra saúde. Como se disse anteriormente, salute é, ao mesmo tempo, "conservação da vida" e "salvação". Relembrese, pois: Ulisses, no episódio do canto das sereias, utiliza-se de uma norma, a "barreira cerácea", pare conservar a vida. Entre os vários significados do termo "salvação", está um que se remete a Fausto: "passar por cima de, saltando" (Ferreira, 1975).

A dialética Ulisses-Fausto, proposta neste texto, impõe para a contemporaneidade um desafio: a satisfação de duas necessidades historicamente determinadas. A primeira delas, "conservar a vida" (Ulisses) implica adelgaçar a referida "barreira cerácea", permitindo uma espécie de "sutura epistemológica", assim como propõe Melo (1991), entre sociedadelcultura e natureza. A satisfação da segunda delas, "passar por cima de, saltando" (Fausto), implica diminuir o abismo existente entre o homem-particular e o homem-genérico, apontando para um outro tipo de "sutura" entre a particularidade (vida cotidiana) e a universalidade.

Formulada dessa maneira, a saúde assume características de uma "necessidade radical" que será mais adiante melhor definida. Procura-se a partir de agora expor as premissas que embasam a referida conclusão. Nesta face, conceitua-se "necessidade" a criticam-se alguns aspectos da concepção marxista da filosofia da história a do marxismo-estruturalista.

No processo argumentativo, deixar-se-á, algumas vezes, de lado a abstração, lançando-se mão de elementos empíricos, advindos do discurso do Movimento Sanitário brasileiro, precisamente aquele expresso no Relatório Final da $8^{\mathrm{a}}$ Conferência Nacional de Saúde, realizada em Brasília, no período de 17 a 21 de março de 1986.
Ele talvez represente uma espécie de redução eidética de todo o ideário do referido movimento, pelo menos até meados da década de 80 .

\section{A SAÚDE E A TEORIA DAS NECESSIDADES}

O conceito de necessidade nunca foi explicitado com a devida clareza por Marx, mas a partir das entrelinhas de suas principais obras, Heller (1986) propõe uma "teoria das necessidades". Mesmo considerando o termo vago e indeterminado, ela o define como sendo o "desejo consciente, aspiração, intenção dirigida em todo momento para um certo objeto a que motiva a ação como tal. $O$ objeto em questão é um produto social independente do farto de que se trate de mercadoria, de um modo de videa ou de 'outro homem"' (Heller, 1986: 170).

Basicamente, ainda segundo Heller (1986), há dois tipos de necessidades. As primeiras, chamadas "existenciais", são motivadas pelo instinto de autoconservação, mas nem por isso podem ser consideradas "necessidades naturais", pois elas são tomadas enquanto tais num contexto social determinado. Entre elas, encontram-se: a necessidade de alimentação, a necessidade sexual, a necessidade de contato social a de cooperação, a necessidade de atividade. Para não deixar dúvida sobre o seu caráter social, Marx diz nos Grundrisse que a fome satisfeita coim faca e garfo é diferente daquela satisfeita com carne crua. Também não se pode identificar tais necessidades coim aquelas próprias dos animais: para se autoconservar o homem precisa de certas condições, vestimenta por exemplo, que não representam uma "necessidade" para outros animais.

As segundas, chamadas de "necessidades propriamente humanas", são aquelas determinadas historicamente e não são dirigidas pare a mera sobrevivência: o descanso superior ao necessário para a reprodução da força de trabalho, uma atividade cultural, a reflexão, a amizade, o amor, a realização de si na objetivação, atividade moral etc. (Heller, 1986).

As "necessidades existenciais" são características do homem-particular a as "necessidades propriamente humanas" identificam-se com o indivíduo, o ser que se eleva da particularidade. Ainda, entre as "necessidades humanas", 
encontram-se aquelas alienadas, tais como o dinheiro, o poder e a posse.

À luz dessa teorização, como poder-se-ia pensar a saúde enquanto uma necessidade? Enquadrando-a no grupo de "necessidades (existenciais)", constrói-se imediatamente um consenso, encerrando-se aparentemente a discussão. Entretanto, argumenta-se que somente um dos aspectos da necessidade de saúde, o "conservar a vida", está sendo considerado. O "passar por cima de, saltando", aspecto mais faustiano do termo, não é contemplado, pois não está dirigido para a mera sobrevivência.

Viu-se anteriormente que a história humana, corn rara exceções: Atenas na Antiguidade e Florença durante o Renascimento, tem sido caracterizada, até agora, pela satisfação (ou tentativa de) apenas das "necessidades existenciais" a das "necessidades humanas" alienadas. Atente-se para o que Heller (1986: 172) conclui a esse respeito: "Com o desenvolvimento do capitalismo (...), as necessidades alienadas têm tomado a dianteira sobre a maioria restante das necessidades propriamente humanas". O mesmo acontece, inclusive, com a satisfação, dentro do mesmo contexto, das necessidades de saúde.

A partir dos estudos de Foucault (1979) sobre o desenvolvimento da medicina social na Alemanha, na França a na Inglaterra, durante os séculos XVIII a XIX, pode-se verificar que todas as três vertentes visam à reprodução da particularidade, satisfazendo (tentando satisfazer) apenas as chamadas "necessidades existenciais", relativas, como foi visto, à autoconservação. Na Alemanha, o alvo é a força do Estado; na Inglaterra, a força de trabalho. Analisando a concepção francesa, Foucault conclui: " $A$ medicina urbana não é verdadeiramente uma medicina dos homens, corpos e organismos, mas uma medicina das coisas: ar, água, decomposição, fermentos; uma medicina das condições de vida e do meio de existência" (Foucault, 1979: 92).

Outros projetos de medicalização, como higiene social, medicina preventiva, medicina comunitária, medicina de família, também não têm o indivíduo (marxista-helleriano) como alvo de suas ações, inclusive a própria medicina clínica, que também tem mitificado a saúde. A esse respeito, é válida a seguinte observação:
"A saúde e a longevidade passaram a ser os novos mitos de um mundo destituído de significado a sentido para a vida. A culpa se torna doença e pagamos o psicanalista para que nos cure. $O$ slogan de que não vale a pena morrer por coisa alguma tem o seu reverso: não vale a pena viver por coisa alguma. A vida é venerada como perseverança de um metabolismo cuidadosamente equilibrado" (Heller, 1993: 43)

\section{O RELATÓRIO DA 8a CONFERÊNCIA NACIONAL DE SAÚDE: O CONFRONTO ENTRE O HOMEM PARTICULAR E O INDIVÍDUO}

Pergunta-se, agora, qual seria o "alvo" do projeto do Movimento Sanitário brasileiro, expresso no Relatório Final da $8^{\mathrm{a}}$ Conferência Nacional de Saúde. Seria, porventura, o indivíduo, na concepção que vem sendo adotada neste texto? Recorde-se mais uma vez: visar à construção do indivíduo significa exigir a satisfação, (ou satisfazer), ao mesmo tempo, das "necessidades existenciais" a daquelas "propriamente humanas".

A hipótese esboçada é a de que o discurso, consubstanciado no referido Relatório, visa à construção do homem-particular e não do indivíduo (marxista-helleriano).

Leia-se um trecho, referente ao tema "Saúde como Direito", do Relatório Final do evento aludido anteriormente:

\section{"Em seu sentido mais abrangente, a saúde é a resultante das condições de alimentação, habitação, educação, rends, meio ambiente, trabalho, transporte, emprego, lazer, liberdade, acesso e posse da terra e acesso a serviços de saúde. É, assim, antes de tudo o resultado das formas de organização social da produção, as quais podem gerar grandes desigualdades nos níveis de vida" (MS, 1986: (04)}

Há dois aspectos, nesse fragmento, que merecem ser evidenciados. O primeiro refere-se ao fato de que a formulação, aí adotada, sobre necessidade de saúde não se restringe à chamada "necessidade de serviços de saúde", nem tampouco trata a saúde como sendo simplesmente a 
ausência de doença. Entretanto, existe aí uma lacuna que merece ser criticada.

Tomada em seu conjunto, essa abordagem de saúde não excede os limites das chamadas "necessidades existenciais". Vaitsman (1992: 170) pondera que "esta definição, embora reconhecendo a importância de elementos extra-econômicos tais como 'liberdade', 'meio ambiente', 'educação' ou 'lazer', os reduz, e com isso reduz também a determinação da doença à determinação das formas da organização social da produção”.

Fugindo do idealismo do preâmbulo da Constituição da Organização Mundial de Saúde, aprovada em 22 de julho de 1946, que afirma ser a saúde um completo bem-estar físico, psíquico e social e não simplesmente a ausência de doença, a concepção, adotada no Relatório, é eminentemente quantitativa, relegando para um segundo plano o qualitativo, característico das "necessidades propriamente humanas" (Heller, 1986). Vejam-se, neste momento, duas das possíveis objeções, que poderiam ser levantadas, à argumentação desenvolvida até agora.

A primeira delas encontrar-se-ia ancorada na crença, muitas vezes oculta, de que existe uma relação do tipo primário-secundário entre as "necessidades existenciais" e aquelas "propriamente humanas". Sendo assim, deve-se, inicialmente, atender aquelas ligadas à autoconservação a só posteriormente satisfazer aquelas outras. Onde se assentaria a base desse modo de pensar? Talvez no Prefácio de "Para a Crítica da Economia Política" de Marx (1991a).

A observação de que "o modo de produção da vida material condiciona o processo em geral da vida social, política e espiritual", muitas vezes, entendida mecanicamente, propiciou criar a versão economicista do marxismo (inclusive aquela que proclama o dogma "em última instância"), além de propagar a crença de que "Com a transformação da base econômica, toda a enorme superestrutura se transforma com maior ou menor rapidez". Reconhece-se que tal transformação é necessária mas não foi (empiricamente) suficiente para criar uma sociedade realmente socialista. A lógica do "primário" e do "secundário" parece advir dessa apressada interpretação de parágrafos, frases, ou, até mesmo, palavras. A questão é posta da seguinte maneira: primeiro deve-se fazer a revolução para depois tratar de aspectos ligados à construção do indivíduo. (Lembre-se aqui da passagem bíblica: primeiro deve-se procurar o reino de Deus, porque posteriormente todas as coisas ser-lhe-ão acrescentadas).

Heller (1982: 162) se contrapõe a essa forma de pensar e a agir: a solução não é "querer primeiro transformar o mundo e os sistemas institucionais acreditando que nossa personalidade mudará automaticamente, assim como não é racional pensar que - mudando a personalidade - o mundo mudará em seguida. Esses dois processos só podem ser realizados sincronicamente e - gostaria de sublinhar isto - não de forma espontânea. Isso significa que lemon de agir levando em conta, constante e conscientemente, ambos os processos: a transformação das instituições e a transformação da personalidade". Aqui não vale a máxima existencialista de que "a existência precede a essência".

O segundo contra-argumento centrar-se-ia nas concepções de "indivíduo", "homem", "necessidades humanas", considerando que elas seriam noções e não conceitos, pois estariam contaminadas por um humanismo e um idealismo estranhos ao marxismo científico. Tal crítica poderia provir evidentemente da corrente de pensamento que mais influenciou o ideário da Saúde Coletiva no Brasil: o marxismo-estruturalista de Althusser. Veja-se, pois, até onde foi tal influência.

\section{O ANTI-HISTORICISMO E O ANTI-HUMANISMO DO MARXISMO-ESTRUTURALISTA DE ALTHUSSER E A SAÚDE COLETIVA}

Em meados dos anos 60, Althusser, lutando teoricamente contra o chamado revisionismo do marxismo, contra a concepção stalinista e contra os veios do humanismo de Garaudy, presentes no Partido Comunista Francês, publica duas obras: "A Favor de Marx" a "Ler O Capital", sendo esta última de autoria coletiva.

Realizando uma leitura "sintomal" (termo emprestado da psicanálise) de "O Capital", o filósofo propõe um anti-historicismo: o presente como iluminador do passado e uma história sem 
teleologia e sem sujeito; e um anti-humanismo teórico, através do estabelecimento do "corte epistemológico" entre o jovem e o velho Marx. Assim pode ser exposta a sua posição antihistoricista:

\section{"A famosa frase, 'a anatomia do homem é a chave da anatomia do macaco', bem} compreendida, não quer dizer outra coisa senão isto: bem compreendida, coincide com esta outra frase da Introdução: não é a gênese histórica das categorias, nem sua combinação em formas anteriores, o que nos dá a sua compreensão, mas o sistema de sua combinação na sociedade atual, que nos abre também a compreensão das formações passadas, dando-nos o conceito de variação dessa combinação. Do mesmo modo, é somente a elucidação do mecanismo do efeito de conhecimento atual que nos pode dar as luzes sobre os efeitos anteriores. A recusa do recurso à origem é, pois, correlata de uma exigência teórica muito profunda, que faz. depender a explicação das formas mais primitivas do modo de combinação sistemático atual das categorias, que se acham em parte nas formas anteriores" (Althusser, 1979b: 68).

Ainda falando sobre história, ele acrescenta: “(...) o texto da história não é um texto em que fale uma voz (o Logos), mas a inaudivel e ilegível anotação dos efeitos de uma estrutura de estruturas" (Althusser, 1979b: 15-16).

A escolha de ambos os fragmentos da obra althusseriana serve para colaborar a tese da influência do marxismo-estruralista na produção teórica da Saúde Coletiva no Brasil. Em um de seus célebres marcos: na conclusão do estudo de Arouca (1975: 237) sobre a emergência da medicina preventiva, pode-se verificar a explicitação dessa influência: "Este instrumental teórico [o materialismo histórico] permitiu que nos afastássemos das sucessões cronológicas, da determinação das influências dos sujeitos, das análises de conteúdo, para a aproximação de um fato social em toda a sua especificidade, ou seja, a emergência a constituição do moviniento preventivista" (os grifos não constam no original).
Tais balizamentos, propostos nesse estudo pioneiro, se utilizam da tese de que "Os homens", como diz Balibar (apud Dosse, 1993), "só aparecem na teoria sob a forma de suportes das relações implícitas na estrutura, a as formas de sua individualidade como efeitos determinados da estrutura". Só recentemente, dentro do próprio Movimento Sanitário, apareceram críticas a essa visão (Campos, 1991).

Contrariamente à versão do marxismo-estruturalista, outro membro, assim como Heller, da chamada Escola de Budapeste, Markus (1974a: 90) refere que

"o homem não é uma cera modelada passivamente por seu meio material e social. (...) O homem só pode modelar sua existência a partir dos materiais que a sociedade coloca à sua disposição (e que durante o processo ativo de assimilação ele modifica igualmente, ou pelo menos é capaz de modificar); assim, também será a situação histórica efetiva que determinará a medida na qual ele poderá operar uma escolha livre e consciente, dentro de certos limites, entre possibilidades socialmente obtidas".

Trazendo à baila os "limites" e as "possibilidades", a formulação acima rejeita a concepção liberal: "cada um faz a sua história do seu jeito". Mas, também, se encontra muito distante da observação de Arouca (1975: 190), quando critica a concepção (liberal) adotada pelo movimento preventivista: "Entendendo que os indivíduos estão submetidos às determinações das formas históricas das relações sociais de produção e reprodução, eles só agem sob estas determinações, de tal forma que afirmá-los como agentes de mudança representa, de um lado, neutralizar conhecimento das determinações $e$, de outro, na ausência destes conhecimentos, a impossibilidade da própria mudança”. Os comentários de Mészáros (1981: 104) parecem incidir sobre o determinismo econômico diluído no fragmento citado:

“Evidentemente, o 'determinismo econômico', nega a inter-relação dialética entre a temporalidade e a atemporalidade, a descontinuidade e a continuidade, a história 
e a estrutura. Opõe à concepção dialética marxista um modelo mecânico no qual uma estrutura atemporal de determinações predomina. (Alguns dos chamados 'marxistas estruturalistas', com sua rejeição antidialética do 'historicismo; são representativos do 'determinismo econômico vulgar', com um disfarce 'estruturalista' culturalmente em moda".

Retome-se, novamente, Markus (1974a). Embora negando a concepção liberal-burguesa de história, ele também repele o argumento de que a história é realizada independentemente da vontade dos homens: dentro de "certos limites", o homem "poderá operar uma escolha livre e consciente".

Ambas as expressões ("certos limites" e "escolha livre a consciente") precisam ser bastante esclarecidas. Os "limites" não podem ser pensados como duas estruturas (infra e supra) que "empurram" o homem em direção a um fim já previamente determinado. O reconhecimento da liberdade a da consciência de escolha (dentro de certos limites) repõe ao homem a decisão sobre as ocorrências históricas.

Heller (1989: 01) chama atenção para alguns aspectos considerados importantes para o esclarecimento dessa complexa questão. Diz ela:

"A teoria segundo a qual os homens fazem sua própria história, mas em condições previamente dadas, contém as teses fundamentais da concepção marxista da história: por um lado, a tese da imanência, e, por outro, a tese da objetividade. (...) Mas essa distinção seria verdadeira tão-somente se 'circunstâncias' e 'homem' fossem entidades separadas. Todavia, essas 'circunstâncias' determinadas, nas quais os homens formulam finalidades, são as relações e situações sócio-humanas, as próprias relações humanas mediatizadas pelas coisas".

Negando ser a história um processo finalístico, (Althusser também nega, embora isto não implique a concordância com a afirmação seguinte:), Heller (1989: 15) observa: “As alternativas históricas são sempre reais: sempre é possível decidir em face delas, de um modo diverso daquele em que realmente se decide. Não era obrigatório que o desenvolvimento social tomasse a forma que tomou, simplesmente foi possivel que surgisse essa configuração (ou outra)"

Convém lembrar que até agora tentou-se apresentar de modo sumário a face anti-historicista de Althusser. Daqui em diante, pretende-se expor a sua outra face: o anti-humanismo. Tal como um anatomista, o filósofo francês, tomando emprestado de Bachelard o conceito de "cesura", reparte a obra de Marx em duas. O "bisturi" alcança o ano de 1845 onde é traçada a "cesura epistemológica" que separa o jovem do velho Marx. As obras de juventude revelam, segundo Althusser (1979a), um Marx influenciado por Kant, Fichte, Feuerbach e Hegel e, portanto, ideológico. Somente a partir de 1845, surge o Marx que funda a ciência da história. O marxismo, em sua versão estruturalista, prefere ao Marx da alienação, do indivíduo ("o indivíduo é o ser social"), da "essência humana", o Marx das relações de produção, dos modos de produção etc. Mostrar que o velho Marx abandona as "noções" da juventude, é tarefa prioritária da obra althusseriana.

Neste momento, caberia uma indagação: será que houve mesmo o referido abandono? O tão propalado rigor intelectual do referido filósofo poderia ser questionado nessa apressada conclusão? O próprio Althusser (1992) oferece uma resposta. Em sua autobiografia, ele confessa que, na época em que publicou "A Favor de Marx" a "Ler O Capital", "não conhecia quase nada da história da filosofia e quase nada de Marx (cujas obras de juventude havia de fato estudado de perto, mas de quem só tinha estudado seriamente o livro I de O Capital, naquele ano de 1964 em que dei um seminário que resultou em 'Ler O Capital".

Contrariamente ao que se fazia em Paris, o marxismo da chamada Escola de Budapeste propunha uma "sutura epistemológica" entre o jovem e o velho Marx: Heller (1991) estuda o indivíduo a partir dos Manuscritos Econômico-Filosóficos de 1844; Markus (1974b) analisa os componentes da "essência humana" a Mészáros (1981), só para citar os principais, investiga a alienação, demonstrando, inclusive, através de citações do original alemão, que o velho jamais abandonou o jovem Marx. 


\section{O CONCEITO MARXISTA-HELLERIANO DE INDIVÍDUO}

Embora, de alguma forma, no presente texto, já tenha sido manifestado o conceito de indivíduo, seria prudente realçar alguns de seus aspectos fundamentais. Neste sentido, remete-se mas uma vez a duas obras: os Manuscritos Econômico-Filosóficos de 1844 (Marx, 1991b; 1983) e Sociologia de la Vida Cotidiana (Heller, 1991).

Inicialmente, expõe-se a dificuldade que tem o referido conceito em alcançar um estatuto teórico. De um lado, necessita-se romper com a abordagem que o senso comum faz dele, não o diferenciando de pessoa, de homem-particular. Do outro, deve-se rechaçar a concepção elaborada pela ideologia burguesa: aquele ser identificado com o ter, aquele que busca satisfazer as "necessidades humanas" alienadas, como o dinheiro, a posse e o poder. Sabe-se, pois, que tais necessidades, devido a sua característica quantitativa, jamais serão de todo satisfeitas, ao contrário daquelas, também já referidas, de base qualitativa: a amizade, o amor... A identificação do indivíduo com o egoísmo é uma invenção (histórica), no Pós-Renascimento, da ideologia burguesa (Heller, 1980)

O que viria a ser então o indivíduo na concepção marxista-helleriana? Observe-se antes um dos trecho que se distancia tanto do marxismo-estruturalista como do positivismo das Regras do Método Sociológico de Durkheim:

\footnotetext{
"Deve-se evitar antes de tudo fixar a 'sociedade' como outra abstração frente ao indivíduo. $O$ indivíduo é o ser social. A exteriorização da sua vida - ainda que não apareça na forma imediata de uma exteriorização de vida coletiva, cumprida em união a ao mesmo tempo com outros -é, pois, uma exteriorização a confirmação da vida social. A vida individual e a vida genérica do homem não são distintas, por mais que, necessariamente, o modo de existência da vida individual seja um modo mais particular ou mais geral da vida genérica, ou quanto mais a vida genérica seja uma vida individual mais particular ou geral" (Marx, 1991b: 170).
}

A partir dessa síntese, constata-se a complexidade de se querer separar - por imposição teórico-histórica - dois aspectos de uma mesma substância: a particularidade e a genericidade. A teorização de Heller (1991) sobre o indivíduo incide na referida dialética. Ele é a ponte entre o particular e o genérico. "Um indivíduo é um homem que se encontra em relação consciente com a genericidade a que ordena sua vida cotidiana com base também nesta relação consciente - evidentemente no seio das condições e possibilidades dadas" (o grifo não consta no original) (Heller, 1991: 55).

Enquanto o homem-particular aspira somente à autoconservação, buscando satisfazer apenas as "necessidades existenciais"; o indivíduo não apenas conserva, mas também recria a sua vida. Este ser se relaciona eminentemente com a satisfação das "necessidades propriamente humanas", visando à apropriação das objetivações genéricas em-si: os utensílios e os produtos, os usos e a linguagem; mas também das objetivações genéricas para-si: a arte, a ciência, a filosofia, o trabalho socialmente necessário, os sentimentos e as paixões (Heller, 1991).

Constitui um grande equívoco querer deduzir as paixões, os afetos e o comportamento moral da autoconservação. Embora se reconheça que sem ela não há vida humana, também não se pode dizer que ela seja a gênese do comportamento humano (Heller, 1991).

A particularidade encontra-se presente em todos os aspectos da vida humana, embora não haja homem-particular que nunca se tenha elevado desta instância. O grau de imersão na genericidade é influenciado fundamentalmente pela classe social, variando, ainda, nos diversos espaços e épocas históricas. Também é necessário dizer que o conjunto dos seres humanos, no modo de produção capitalista, não desenvolve sua individualidade.

O fato contraditório deste modo de produção é que ele acena com a possibilidade de exteriorizar - como nunca - os componentes da "essência humana", entretanto o trabalho alienado, como diz Marx (1983), transforma a vida humana em um meio de vida.

Findo o interregno teórico-conceitual sobre filosofia da história e indivíduo, vale ressaltar que o 
"mergulho", a fim de colher subsídios para confirmação ou não da hipótese que está sendo analisada, na obra do jovem Marx não é, nem poderia ser um "mergulho" sem pré-conceitos. Preferiu-se ao jovem Marx de Althusser (1979) ou de Astrada (1968), o jovem Marx da Escola de Budapeste, reconhecendo-se, pois, que "Os sistemas filosóficos são infinitos, tal como as obras de arte. Por isso, as suas possibilidades de interpretação são também inesgotáveis. Uma compreensão pode contrapor-se a outra, mas sempre de modo a que ambas possam ser aceitas como compreensão que - como qualquer outra compreensão - contém o momento do mal-entendido" (Heller, 1983a: 38).

\section{A HIPÓTESE RESISTE AO FALSEAMENTO?}

Prosseguindo-se a análise, é necessário retomar a hipótese que está sendo aqui analisada: o alvo do texto do Relatório da $8^{\mathrm{a}}$ Conferência Nacional de Saúde é o homem-particular e não o indivíduo no sentido marxista-helleriano. Atente-se, agora, para um outro trecho do Relatório que praticamente repete a essência daquele que foi citado anteriormente:

\section{O direito à saúde implica garantir: "trabalho} em condições dignas, com amplo conhecimento e controle dos trabalhadores sobre o processo e o ambiente de trabalho; alimentação para todos, segundo as suas necessidades; moradia higiênica e digna; educação e informação plenas; qualidade adequada do meio ambiente; transporte seguro e acessível; repouso, lazer e segurança; participação da população na organização, gestão e controle dos serviços e ações de saúde; direito à liberdade, à livre organização e expressão; acesso universal e igualitário aos serviços setoriais em todos os niveis" (MS, 1986: 05).

Percebe-se novamente que a maioria das necessidades listadas são eminentemente "existenciais", entretanto aparecem três necessidades que poderiam refutar a hipótese levantada: o trabalho, a participação política e a liberdade, dada a íntima relação que elas têm com a genericidade. Mesmo assim, enfrentando o risco do falseamento, marter-se-á a hipótese original; tentando-se monstrar que, mesmo considerando o excesso de significação, a formulação, tal como aparece no texto, não rompe necessariamente com o liame da particularidade, não se dirigindo, portanto, para a genericidade.

Construam-se, pois, os argumentos. Em relação ao trabalho, o texto não faz uma diferença fundamental entre a atividade como "meio de existência" e aquela enquanto componente da “essência humana". Segundo Mészáros (1981: 85), Marx "traça a linha conceitual de demarcação entre trabalho como 'Lebensäusserung' (manifestação de vida) e como 'Lebensentäusserung' (alienação da vida). O trabalho é 'Lebensentäusserung' quando 'eu trabalho para viver, para produzir um meio de vida, mas meu trabalho não é vida, em si, isto é, minha atividade me é imposta 'por uma necessidade externa', em lugar de ser motivada por uma 'necessidade interior'.

Discordando da posição arendtiana, Heller (1991: 120) utiliza a seguinte diferença entre work e labour. "Se um produto não satisfaz nenhuma necessidade social ou é fabricado em um tempo de trabalho superior ao socialmente necessário, não se pode falar de work, mas sim de labour". O primeiro significado refere-se eminentemente à genericidade $\mathrm{e} o$ segundo, à particularidade. O controle, como diz o Relatório, sobre o processo e o ambiente de trabalho é, pois, insuficiente para caracterizá-lo como work.

Ainda é necessário desfazer uma confusão: quando, na sociedade moderna, se desejam satisfazer outras necessidades que não estejam intimamente ligadas à autoconservação mas que possam ser reduzidas ao possuir, não se pode, ainda, dizer que elas visam à individualidade. Heller (1991) chama esse fenômeno de "inchamento" da particularidade, sendo assim o trabalho "é levado a cabo em função da conservação da particularidade".

Embora se reconheça a genericidade do trabalho, diz Heller (1991: 124): "no momento em que o trabalho como atividade genética que transcende a cotidianidade chega a ser totalmente alienado, a execução de um trabalho perde toda forma de auto-realização e serve única e exclusivamente para a conservação da existência particular, ou seja (...) para a conservação da particularidade”. 
Quanto à "participação da população na organização, gestão e controle dos serviços e ações de saúde", reconhece-se que para o exercício da atividade política é necessária uma certa distância do penssamento cotidiano, entretanto isto não quer dizer que o pensamento politico esteja livre do caráter fetichista daquele pensamento (Heller, 1991).

A referida participação não é antagônica à ideologia do Estado de bem-estar, onde novamente a particularidade é priorizada, sendo considerado apenas o primeiro significado de saúde - o "conservar a vida". Heller chama atenção para o que ocorreu, nos primórdios, com os movimentos operários. O apelo à superação da particularidade provinha não do conteúdo de reivindicações, pois visavam somente à autoconservação: pão, casa, horário de trabalho mais breve, mas sim dos meios dos quais se serviam para a sua consecução: "Se requeria compromisso social, solidariedade, tenacidade na greve, e não era certo que estes meios levassem rapidamente ao resultado esperado. Portanto, a participação na luta puramente econômica já induzia os operários a uma nova forma de vida cotidiana, não orientada somente para a particularidade; por isso Marx via nos operários organizados a irradiação da dignidade humana" (Heller, 1991: 180).

Referindo-se ao momento atual dos movimentos operários europeu a norte-americano, Heller (1991: 180-181) constata uma modificação de atitude:

\section{“A participaçdo neste tipo de luta já não requer a superação da particularidade a já não constitui uma atividade social que surge de uma visão totalmente nova da sociedade em seu conjunto. O fim é a satisfação das motivações particulares no seio de uma determinada ordem social. Por esta razão os movimentos econômicos têm podido ser rapidamente integrados à ordem econômica capitalista; enquanto os ideais, sua propaganda ideológica não se distancia muito da ideologia oficial do Estado de bem-estar”.}

Poder-se-ia dizer que enquanto as reivindicações do referido movimento estiverem restritas à particularidade, o movimento não se liber- tará da integração ao capitalismo. O risco, assim exposto, poderia ser aplicado ao Movimento Sanitário brasileiro quando Pica desatento ao segundo significado de saúde - o "passar por cima de, saltando", pois este tenta romper com os liames da particularidade.

Por último, fala-se do "direito à liberdade, à livre organização a expressão". A primeira crítica à formulação refere-se a sua generalidade, dificultando assim a análise. $O$ texto não faz distinção entre liberdade cotidiana a liberdade genérica. Embora o reconhecimento dessa diferença seja importante, a crítica incidirá mais no aspecto do "direito" do que na própria "liberdade". Acredita-se que duas observações, advindas da sociologia helleriana, são suficientes para encerrar os argumentos aqui elencados. A primeira constata que "Sempre e em cada época o direito - inclusive na forma de direito consuetudinário - tem regulado a vida cotidiana dos homens, limitando a validade dos interesses do particular ao que é lícito". A segunda afirma que o direito estabelece os limites da particularidade em vez de desenvolver a individualidade (Heller, 1991).

Terminada a exposição dos três argumentos, acredita-se, nos moldes popperianos, que a hipótese parece ter resistido à primeira tentativa de falseamento. Portanto, seria razoável concluir que o "alvo" do Relatório da 8를ência Nacional de Saúde teria sido o homem-particular e não o indivíduo, no sentido marxista-helleriano, mesmo considerando que equivocadamente no próprio texto do documento tenha aparecido a seguinte redação: "Direito à saúde significa a garantia, pelo Estado, de condições dignas de vida e de acesso universal e igualitário às ações e serviços de promoção, proteção e recuperação de saúde, em todos os seus níveis a todos os habitantes do território nacional, levando ao desenvolvimento pleno do ser humano em sua individualidade" (MS, 1986: 04) (os grifos não constam no original).

Qual seria então este "indivíduo"? Talvez fosse o cidadão, embora não seja objetivo deste texto a verificação de tal hipótese. Caso o "alvo" fosse mesmo o indivíduo, o texto deveria tratar a saúde como sendo uma necessidade radical, principalmente levando-se em conta o seu segundo significado que apontaria necessariamente para a genericidade. Heller (1983a: 143) 
denomina carecimentos radicais "os carecimentos que se formam nas sociedades fundadas em relações de subordinação a de domínio mas que não podem ser satisfeitos quando se restam no interior delas. São carecimentos cuja satisfação só é possível com a superação dessa sociedade”.

Tomando-se como base a saúde, expõem-se agora alguns exemplos de carecimentos radicais formulados por Heller (1983a): a exigência de um tempo livre maior do que o necessário para a mera reprodução, repondo o trabalho como componente da essência humana e não exclusivamente um meio para garantir a existência, sendo o resto do tempo destinado às objetivações genéricas para-si; a superação do conflito entre os gêneros, favorecendo a saúde mental e sexual de ambos e promovendo a eliminação das formas de violência adotadas para se exercer o poder; a luta contra a catástrofe ecológica; o modo de viver em "comunidades" (marxistahellerianas) livremente escolhidas, onde as potencialidades humanas possam ser desenvolvidas; a eliminação da guerra e dos armamentos; a completa eliminação da fome a da miséria; a diminuição da defasagem entre cultura e cultura de massa. Todas essas necessidades se relacionam com o segundo significado de salute, isto é, o "passar por cima de, saltando". Todas elas procuram romper com os limites da vida cotidiana, por isso os movimentos identificados com elas, podem ser considerados movimentos revolucionários, no sentido helleriano do termo: "Uma teoria revolucionária fala a todos os que têm carecimentos radicais e, portanto, não pode referir-se apenas a uma classe determinada. Naturalmente, refere-se também à classe operária" (Heller, 1982: 46). Sendo assim, além da referida classe, outros movimentos que exprimam tais carecimentos, como o feminista, o ecológico, o sanitário, poderão tornar-se sujeitos de transformação através da revolução social total, revolucionando-se, inclusive, o modo de vida.

\section{CONCLUSÂO}

Entenda-se, finalmente, o que motivou a utilização, no início deste texto, de uma figura de palavra - a sinédoque - que se constitui no aumento ou na diminuição do real sentido de um termo. A figura está presente quando se emprega a parte pelo todo; o singular pelo plural; o gênero pela espécie; a matéria pelo objeto; e também, o indivíduo pelo conjunto, como aqui foi usado.

A fim de que se possa realmente construir a sinédoque - este é o desafio - é necessário um distanciamento. Ulisses já não seria uma personagem das epopéias gregas, mas sim um indivíduo (conjunto de seres que realizaram, inclusive, a passagem da natureza para a humanidade). O Ulisses em-si, desenvolvendo as potencialidades da "essência humana": trabalho, socialidade, consciência, liberdade e universalidade, poderia tornar-se, também, o Ulisses para-si.

Fausto, todavia, já não seria uma personagem do imaginário renascentista, mas sim um indivíduo (conjunto de seres humanos que através da revolução social total conquistaram a diminuição do fosso existente entre a particularidade e a genericidade). O Fausto para-si já não necessitaria abdicar do Fausto em-si.

Sublinha-se, entretanto, que a construção da sinédoque Ulisses-Fausto para-nós, cuja formulação seria idêntica aos significados de salute ("conservar a vida" a "passar por cima de, saltando"), consiste apenas numa possibilidade. Como não existe um sentido (teleologia) na história, ela só poderia ser garantida se os movimentos identificados com as necessidades radicais criassem um sentido para esta história (Heller, 1989). Não há nada (astúcia da razão) na própria história que garanta esse fim como uma necessidade. Existem outras possibilidades, não necessariamente formuladas a partir da escatologia "socialismo ou barbárie".

Uma delas: de tanto ser tratada como animal, uma parte da humanidade, a horda da pólis, as crianças embrutecidas, os famintos, os loucos, os miseráveis, o homem-caranguejo, o homem-gabiru, o homem-barata, será deshumanizada dentro das sociedades forjadas na exploração do homem pelo homem. Corre-se o risco de se retirar a "barreira cerácea" dos ouvidos dos marinheiros de Ulisses, propiciando, sem recriação, sem subterfúgio, sem "sutura", a sua volta ao passado, à natureza, à beleza do canto das sereias, enfim, à morte.

Outra formulação, entre tantas possíveis: Fukuyama (1992), a partir de uma adulteração 
do pensamento de Hegel (Anderson, 1992), decreta o "fim da história", "condenando" a humanidade e enclausurar-se nas teias da democracia liberal, onde só resta o direito de votar e fazer compras. Fausto recusa o tranqüilizante oferecido pelo "último" pensador. Neste caso, prefere Mefistófeles.

\section{RESUMO}

\section{MELO-FILHO, D. A. Repensando os} Desafios de Ulisses e Fausto: A Saúde, o Indivíduo e a História. Cad. Saúde Públ., Rio de Janeiro, 11 (1): 05-33, jan/mar, 1995.

Em torno de duas sinédoques históricas, Ulisses e Fausto, o texto retoma a etimologia do termo saúde (do latim salute), tratando-a como uma unidade entre as "necessidades existenciais" e as "necessidades propriamente humanas", que desemboca no desafio de satisfazer o "conservar a vida" e, ao mesmo tempo, o "passar por cima de, saltando". Ambos os significados encontram-se, respectivamente, presentes na atitude de Ulisses em não sucumbir ante o canto das sereias e no desejo de Fausto em elevar-se da vida cotidiana. Criticam-se alguns aspectos da concepção marxista da filosofia da história e do marxismo-estruturalista de Althusser. Analisa-se, ainda, à luz da teoria marxistahelleriana, a hipótese de que o alvo do Relatório Final da $8^{\mathrm{a}}$ Conferência Nacional de Saúde teria sido o homem-particular e não o indivíduo, pois a saúde ali é tratada apenas como uma "necessidade existencial", não objetivando o humano-genérico. Como desafio teórico, o texto, visando ao devir do indivíduo, recomenda, finalmente, a construção de "suturas epistemológicas" entre natureza/sociedade, entre vida cotidiana/universalidade e entre o jovem e o velho Marx.

Palavras-Chave: História a Saúde; Indivíduo e Saúde; Sociedade a Saúde; Necessidades Humanas e Saúde

\section{REFERÊNCIAS BIBLIOGRÁFICAS}

ALTHUSSER, L., 1979. A Favor de Marx. 2ae ed., Rio de Janeiro: Zahar.

1979b. De o capital à filosofia de Marx. In: Ler O Capital (L. Althusser; J. Rancière \& P. Macherey), pp. 11-74, Vol. 1, Rio de Janeiro: Zahar. 1992. O Futuro Dura Muito Tempo. São Paulo: Companhia das Letras.

ANDERSON, P., 1992. O Fim da História: de Hegel a Fukuyama. Rio de Janeiro: Jorge Zahar.

AROUCA, A. S. S., 1975. O Dilema Preventivista: Contribuição para a Compreensão e Crítica da Medicina Preventiva. Tese de Doutorado, Campinas: Faculdade de Ciências Médicas, Universidade Estadual de Campinas.

ASTRADA, C., 1968. Trabalho e Alienação. Rio de Janeiro: Civilização Brasileira.

BENJAMIN, W., 1985. Teses sobre filosofia da história. In: Walter Benjamin (F. R. Kothe, org.), pp. 153-164, São Paulo: Ática

CAMPANELla, T., s/d. A Cidade do Sol. Lisboa: Guimarães.

CAMPOS, G. W. S., 1991. A militância em saúde pública e a luta em defesa da vida. In: A Saúde Pública e a Defesa da Vida, pp. 13-36, São Paulo: Hucitec.

DOSSE, F., 1993. História do Estruturalismo: o Campo do Signo, 1945/1966. São Paulo: Ensaio/ Campinas: Editora da Universidade Estadual de Campinas.

FERREIRA, A. B. H., 1975. Novo Dicionário da Língua Portuguesa. Rio de Janeiro: Nova Fronteira.

FOUCAULT, M., 1979. O nascimento da medicina social. In: Microfísica do Poder, pp. 79-98, 9를. Rio de Janeiro: Graal.

FUKUYAMA, F., 1992. O Fim da História e o Último Homem. Rio de Janeiro: Rocco.

GOETHE, J. W., 1984. Fausto. Rio de Janeiro: Tecnoprint.

GONÇALVES, R. B. M., s/d. Processo de Trabalho em Saúde. São Paulo: Departamento de Medicina Preventiva/FM/USP. (Mimeo.)

HELLER, A., 1980. El Hombre del Renacimiento. Barcelona: Península.

1982. Para Mudar a Vida: Felicidade, Liberdade e Democracia. São Paulo: Brasiliense. ,1983a. A Filosofia Radical. São Paulo: Brasiliense. 
,1983b. Sobre os lnstintos. Lisboa: Presença.

1983c. Aristóteles y el Mundo Antiguo. Barcelona: Península.

1986. Teoría de las Necesidades en Marx. Barcelona: Península.

1989. O Cotidiano a História. $3^{\mathrm{a}}$ ed., Rio de Janeiro: Paz e Terra.

1991. Sociología de la Vida Cotidiana. Barcelona: Península.

1993. Uma Teoria da História. Rio de Janeiro: Civilização Brasileira.

HOMERO, s/d. Odisséia (em versos). Rio de Janeiro: Tecnoprint.

KEHL, M. R., s/d. A razão depois da queda (utopias e psicanálise). In: Tempo do Desejo (H. R. Fernandes, org.), pp. 35-63, São Paulo: Brasiliense.

MARKUS, G., 1974a. A Teoria do Conhecimento no Jovem Marx. Rio de Janeiro: Paz a Terra.

1974b. Marxismo y Antropologia. Barcelona: Grijalbo.

MARX, K., 1983. Manuscritos econômico-filosóficos de 1844 (primeiro manuscrito). In: Conceito Marxista do Homem (Erich Fromm), pp. 83-170, Rio de Janeiro: Zahar.

1991a. Para a crítica da economia política (Prefácio). In: Marx (J. A. Giannotti, seleção dos textos), pp. 27-32, São Paulo: Abril Cultural.

1991b. Manuscritos econômico-filosóficos (terceiro manuscrito). In: Marx (J. A. Giannotti, seleção dos textos), pp. 159-208, São Paulo: Abril Cultural. 1991c. Para a crítica da economia política (Introdução). In: Marx (J. A. Giannotti, seleção dos textos), pp. 03-25, São Paulo: Abril Cultural.

MATOS, O., 1993. A melancolia de Ulisses: a dialética do iluminismo e o canto das sereias. In: Os Sentidos da Paixão (A. Novaes, org.), pp. 141-157, São Paulo: Companhia das Letras.

MELO, J. A. C., 1991. Apresentação. In: A Saúde Pública e a Defesa da Vida (G. W. de Sousa Campos), pp. 9-10, São Paulo: Hucitec.

MÉSZÁROS, I, 1981. Marx: a Teoria da Alienação. Rio de Janeiro: Zahar.

MORUS, T., s/d. A Utopia. Rio de Janeiro: Ediouro.

MS (Ministério da Saúde), 1986. Relatório Final da $8^{a}$ Conferência Nacional de Saúde de 17 a 21 de março de 1986, Brasilia, DF: MS. (Mimeo.)

PESSANHA, J. A. M., 1978. Os Pré-Socráticos: Vida e Obra. 2ª ed., São Paulo: Abril Cultural.

SARTRE, J. P., 1973. A Imaginação. São Paulo: Difusão Européia do Livro.

TAMAYO, R. P., 1988. El Concepto de Enfermedad: su Evolución a Través de la Historia. Tomo I, México: Fondo de Cultura Econômica.

TESTA, M., 1992. Pensar em Saúde. Porto Alegre: Artes Médicas.

VAITSMAN, J., 1992. Saúde, cultura e necessidades. In: Saúde: Coletiva? Questionando a Onipotência do Social (S. Fleury, org.), pp. 157-173, Rio de Janeiro: Relume-Dumará. 


\section{Debate sobre o Artigo de Melo-Filho \\ Debate on the Paper by Melo-Filho}

\section{José Ricardo de C. M. Ayres \\ Faculdade de Medicina \\ Universidade de São Paulo}

"A técnica haverá de sucumbir por não ter a força de desejar", diz Ortega y Gasset. A contundência do filósofo ressalta a relevância do artigo de Djalma Agripino de Melo Filho, sem dúvida uma das mais oportunas a instigantes reflexões recentemente produzidas no campo da Saúde Coletiva no Brasil. Visando à libertação das coerções da natureza e dos preconceitos, nós, os "modernos", acabamos por fazer equivaler a "razão prática", essa esfera de representações e anseios repletos de significação e laboriosamente construídos na fina tessitura das experiências intersubjetivas, ao estrito domínio das habilidades cognitivas e transformadoras da ciência e da técnica. É dos prejuízos éticos dessa colonização tecnicista da razão prática que trata o autor.

Através da força simbólica dos mitos de Ulisses e Fausto, Melo Filho desenvolve uma iluminadora hermenêutica do discurso sanitário, expondo suas fragilidades por referência a importantes valores de seus agentes privilegiados. As duas personagens, na condição de sinédoques, mostram-nos que, na busca da luz e da libertação, o Homem nega sua natureza e perde-se de si mesmo. Analogamente, buscando garantir aos indivíduos a saúde como bem, nega-se a necessidade de "individualização" inerente à saúde como valor. A "negação desta negação" fica interditada, por sua vez, pela perigosa "irracionalidade" do conteúdo prático (simbólico e "desejante") que lhe é inexorável.

Para a elucidação desta perspectiva crítica, o autor recorre ao materialismo histórico, ou, mais particularmente, à filosofia da práxis, a esse é mais um entre os inúmeros méritos deste trabalho. Buscar no marxismo caminhos para a compreensão dos movimentos recentes do pensamento sanitário brasileiro, justo nesse momento de importante inflexão por que passam ambos, constitui uma tarefa corajosa e difícil, mas fecunda, como podemos constatar na leitura de Melo Filho.
Entre as diversas questões suscitadas pela perspectiva crítica a que nos convida o autor, há uma que me parece especialmente "desafiadora", e que não se restringe ao campo sanitário, estendendo-se ao debate filosófico contemporâneo como um todo (Habermas, 1990). Trata-se de pensarmos até que ponto a filosofia da práxis permite superar as aporias da razão moderna, tão agudamente apontadas no texto. Não padece a dialética do trabalho da mesma necessidade do fundamento universal do conhecimento, a qual continuaria nos precipitando em direção ao "pacto fatal" com Mefistófeles? Melo Filho tem razão quando identifica na chamada Escola de Budapeste uma vertente teórica que escapou às armadilhas de um marxismo com pretensões cientificistas. Mas até que ponto a teoria das necessidades consegue, efetivamente, incluir o propriamente humano na apreensão da dialética entre trabalho e socialidade?

Não há dúvida de que a teoria das necessidades, enquanto totalidade interpretativa, rompe com a aspiração objetivista do conhecimento do fato humano. A teoria aqui é sempre entre sujeitos e situações materialmente configurados, intermediada e estabelecida por valores humanos, os quais só adquirem positividade a partir desses sujeitos a situações. Não é, portanto, o distanciamento, a neutralidade, o alcance do "ponto arquimediano" que elucida o fato humano, mas a reflexividade. Contudo, se não aderimos à filosofia idealista de uma teleologia histórica, orientada pela e para a realização de um "espírito humano" universal, de onde poderemos obter a garantia de que alcançamos, nessa reflexividade, conhecimento positivamente relacionado aos nossos valores emancipatórios? Da consciência que obtemos através e contra os processos de reificação que alienam o Homem de si mesmo, do progressivo auto-reconhecimento deste Homem no mundo que produz por suas ações, propõe Lukács. Ora, permanece o problema de buscar a "melhor" consciência, aquela menos alienada, a visão mais universal do fato humano. Está-se, assim, diante do paradoxo de uma razão que busca o universal negando a universalidade. A assunção do caráter essencialmen- 
te negativo de uma dialética materialista é urna das possíveis soluções frente a essa aporética da reflexividade (Adorno, 1990). Contudo, o preço a pagar é o de reconduzir a um patamar incomodamente especulativo uma filosofia enraizada no ideal de conciliar reflexão e ação. Já o marxismo de Budapeste buscou manter essa conciliação à custa da problemática identificação entre produção e razão. Em termos bastante sintéticos, o que, segundo essa Escola, constitui e emancipa o indivíduo humano é o que se logra enxergar e construir no modo de produzir/reproduzir a existência material. O conceito raiz de necessidade radical expressa essa unidade teórica entre uma perspectiva racional emancipadora e formas determinadas de produção e consumo. Mas, não estaremos recolocando, assim, a prerrogativa da verdade e, em consequiência, da decisão emancipadora em algum lugar alheio à razão prática?

Certas tensões teóricas surgidas no texto de Melo Filho parecem sintomáticas dessa aporética, como uma certa tendência à dicotomização entre necessidades existenciais e radicais, como se fossem entidades distintas, por vezes; o heterodoxo recurso à legitimação popperiana da hipótese desenvolvida, não pela heterodoxia, naturalmente, mas pela noção de não-refutabilidade, só possível logicamente se admitida uma autoridade autônoma à positividade factual; ou a contradição entre a "recusa" do valor emancipador dos interesses "particularistas" da saúde e a concepção não-teleológica de história.

Sem defender qualquer forma de relativismo ontológico, ou negar a necessidade de hierarquizar as dimensões da existência apreensíveis no conhecimento dos fatos humanos, parece-me que o desafio da razão emancipadora vai alem da superação do idealismo filosófico ou do objetivismo. Parece necessário assumir mais radicalmente a historicidade de toda representação (Gadamer, 1991), ancorando na dimensão ética a universalidade do huma-no-genérico. Não há produto da razão, sequer o mais inocente conceito, que possa ser gerado fora do compartilhamento material e simbólico da vida. Querer partir dessa experiência intersubjetiva, que é sempre também ética e estética, a colocar-se em algum ligar epistêmico definitiva e universalmente esclarecedor, faz lembrar a epopéia de um outro personagem mítico, ainda mais ancestral que Ulisses e Fausto, e que talvez tenha também algo a dizer-nos a respeito. Trata-se de Gilgamesh, sábio e poderoso rei da Babilônia. Encorajado por ter feito de Uruk a mais poderosa cidade de seu tempo, Gilgamesh resolve partir em busca da imortalidade, equiparar-se aos deuses. Na etapa final de sua sofrida epopéia, entretanto, o herói escuta de Utnapishtim, o Longínquo, guardião da imortalidade, a mensagem que expõe todo o paradoxo de seu intento: "Não existe permanência. Acaso construímos uma casa para que fique de pé para sempre, ou selamos um contrato que valha por toda a eternidade? Acaso os irmãos que dividem uma herança esperam manté-la eternamente, ou o período de cheia do rio dura para sempre? Somente a ninfa da libélula despe-se da larva e vê o sol em toda a sua glória. Desde os dias antigos, não existe permanência. Como são parecidos os adormecidos e os mortos, eles são como um retrato da morte. $O$ que existe entre o servo e o senhor depois de ambos terem cumprido seus destinos?" (Anônimo, 1992: 147).

\section{REFERÊNCIAS BIBLIOGRÁFICAS}

ADORNO, T. W.,1990. Dialética Negativa. Madrid: Taurus.

ANÔNIMO, 1992. A Epopéia de Gilgamesh. São Paulo: Martins Fontes.

GADAMER, H-G,1991. Verdad y Método. Salamanca: Sígueme.

HABERMAS, J., 1990. O Discurso Filosófico da Modernidade. Lisboa: Dom Quixote.

\section{Maria Cecília de S. Minayo \\ Vice-Presidência de Ensino e Informação Fundação Oswaldo Cruz}

\section{Repensando os Desafios de Ulisses e Fausto}

O texto de Djalma A. Melo Filho promove um encontro dos que atuam na área de saúde com os ideais e as entranhas de sua práxis. Utilizando-se das metáforas de Ulisses (Homero) e Fausto (Goethe) o autor defende a tese de que o setor saúde no Brasil, mesmo na sua expressão considerada mais progressista, o mo- 
vimento sanitário, não conseguiu ultrapassar, em sua proposta, o nível das "necessidades existenciais". Por extensão, não tem contribuído para a construção do "indivíduo" que exigiria para se constituir, a "satisfação de necessidades propriamente humanas". O artigo é provocador porque de um lado coloca uma tese de forma incisiva; de outro, no seu desdobramento de metáforas e entrecortado exercício de hermenêutica, permite infinitas interpretações: é um texto polissêmico.

Quando o autor, no decorrer do trabalho, vai progressivamente conceituando saúde "salute"; "salvação"; "passar por cima e saltar"; "prazer dos sentidos"; "prazer do equilíbrio"; "realização de qualidade e não apenas quantidade"; "liberdade aliada à socialidade"; "trabalho como componente da essência humana"; assim por diante - fica claro que sua formulação não pode set reduzida a um conceito privativo do setor. Pelo contrário, talvez em estrito senso, seja este um campo de conhecimento e de práticas onde menos militam os profissionais de saúde. No amplo espetro do prazer, da socialidade; da contemplação, da liberdade, do trabaIho criador, possivelmente os artistas, os poetas, os monges, e quem sabe? os boêmios, sejam os atores mais significativos e definidores do âmbito e dos "ilimites" da saúde.

$\mathrm{Na}$ área considerada profissional, a barreira cerácea, dada pelas várias estruturas de pensamento e ação, contra o canto da sereia do diletantismo acadêmico ou contra a pulverização de ações, permitiu colocar como meta apenas "a conservação da vida" enquanto limite de possibilidades. E quanto a isso se podem produzir várias ilações.

A primeira é de que, do ponto de vista pragmático, a área da saúde foi sempre caudatária da hegemônica ideologia médica e a medicina sempre atuou dentro da causalidade biológica em função da doença e da ameaça da morte, portanto, para a "conservação da vida". Em segundo lugar, o movimento sanitário, como detecta o autor, fundamentou-se numa corrente mecanicista do marxismo, capitaneada por Althusser, que realizou duas cisões no campo do conhecimento e das práticas: menosprezou os atores e as relações sociais, separando-os das responsabilidades com as mudanças estruturais; negou a história e ressaltou os determinismos das forças produtivas. Essas barreiras ceráceas nos ouvidos de Ulisses, colocadas talvez para atender aos conselhos da feiticeira Circe receosa dos maviosos cantos da sereia aqui, no entanto, encontraram a tentação do vôo fáustico como forma de praticar a política. A cisão teórico-prática entre estruturas e relações foi acompanhada pela negação das individualidades, do papel dos atores e do peso da cotidianeidade na produção e na reprodução. A questão era investir nas mudanças das estruturas a para isso na participação do poder oficial.

Esses problemas já levantados pelo autor poderiam ser ampliados para se entender a prática das esquerdas brasileiras, nas quais nos incluímos como contemporâneos e patícipes. A cera nos ouvidos contra o canto das sereias acabou por criar barreiras de comunicação ou contraditória e involuntariamente levou-nos para o espaço dos personalismos exarcebados, para o deslocamento entre teoria a vida, para a incompetência de promover a isonomia das forças em oposição.

Mas esse texto, Djalma o escreveu pare comemorar os 40 anos da Escola Nacional de Saúde Pública, esta jovem senhora, emblemática da saúde pública e do movimento sanitário. Olhando-a enquanto ator e personagem, Ulisses e Fausto se misturam. De um lado, o pragmatismo da área a envolve mais que a qualquer outra instituição do setor. Da mesma forma é lhe constante a tentação do retorno ao passado do carisma e do mito. De outro lado, a sedução fáustica da "negação de qualquer limite", "de apoderar-se do que parecer", "e de fazer a sua moda" promove a sua "volta" ao futuro temerário universalista que se confunde com o retorno ao passado. Porém sua madura juventude há de encantar-se corm o $\log o s$ e fazê-la transpor a soleira do instinto para se institucionalizar na socialidade, na consciência, no trabalho a na universalidade. É verdade que estamos no mundo das metáforas e dos símbolos. Mas mesmo assim, vale lembrar, parafraseando o poeta Thiago de Melo, que talvez "não exista um caminho novo. $\mathrm{O}$ que existe de novo é o jeito de caminhar". 


\section{Luiz Fernando D. Duarte}

Departamento de Antropologia

Museu Nacional

\section{Dos Sonhos do Ocidente: Considerações Críticas a Propósito do Texto}

Acredito que ainda se considere muito generalizante como sendo a espinhosa tarefa da Antropologia conhecer e compreender as outras sociedades em que se organizou a espécie humana: mormente aquelas que chamamos de "primitivas". Sem sombra de dúvida, no entanto, a tarefa verdadeiramente espinhosa que temos de enfrentar é a de conhecer e compreender estas nossas sociedades (e sua cultura). E já não mais apenas porque temos consciência de que é somente através de nossos quadros analíticos que podemos interpelar a alteridade (e constituí-Ia mesmo), mas sobretudo porque - após um longo exercício de comparações antropológicas não podemos nos eximir de tentar relativizar nossos valores, de observá-los estrategicamente como se outros fossem, distantes da espessura em que a crença social os entranha.

Uma crescente atenção tem sido dada, nesse sentido, à busca e análise do que mais radicalmente qualificaria nossa experiência histórica, de um ponto de vista comparado. Boa parte dos esforços tem se visto assim às voltas com o estatuto da Pessoa na cultura ocidental moderna, já porque esse é um nódulo esclarecedor dos valores estruturantes em toda cultura, já porque a cosmologia ocidental o investe de uma particular importância, de uma condição verdadeiramente axial. O tema do "individualismo" herdado da crítica ideológica do século XIX, tem ganho novos foros de legitimidade, por exemplo, na releitura empreendida por L. Dumont das indicações da história social de M. Weber a propósito da constituição do ideário da "liberdade" a da "igualdade" no Ocidente modemo. Ele está presente também - ainda que sob outros nomes - na definição da "sociedade disciplinar" de M. Foucault, no "processo civilisatório" de N. Elias ou na revisão do "mundo psicologizado" de Ch. Lasch, de R. Sennett ou de M. Gauchet. A Antropologia não pode se queixar assim de estar sozinha nessa dura tarefa de dessacralizar (ao dessubstancializar) os nossos mais profundos valores: também da História, da
Psicologia Social e de algumas das Psicanálises emergem significativas contribuições à compreensão da radical singularidade de nossa concepção de Pessoa: o indivíduo portador de uma "liberdade", "igualdade" e "singularidade".

Um esforço particularmente dedicado se impõe nessa espinhosa tarefa: o de fazer ver que o empreendimento crítico dessa comparação dessacralizante não significa em si uma desqualificação" desses valores. Não se trata de paralisar a cultura ocidental moderna no que tem de mais autêntico ou dinâmico porque ela acredita nisto ou naquilo. Toda cultura tem que fazer com que seus membros acreditem em algo, tem que se propor um objetivo - por mais utópico ou fantástico que possa parecer. Mas esta nossa cultura tem ao lado de seus valores por assim dizer mais "substantivos" (como os da "liberdade" e da "igualdade"), outros mais "instrumentais" aos quais ela não pode deixar de estar subordinada. Um deles é o da "verdade" - na medida em que se entenda nessa categoria um mandamento de permanente inquietude, de insatisfação que não se contenta nem em si mesma, mas que sempre mais além demanda e inquire.

Não é à toa assim que D. A. de Melo Filho invoca a imagem do Fausto para expressar a dimensão mais abrangente do ideal de "indivíduo" de que está tratando. Spengler já o havia feito ao chamar de faustiana a esta civilização: a que sempre anseia, a que se redime mesmo no final da peça de Goethe - após tantos erros e horrores por ter sempre desejado.

$\mathrm{O}$ autor sugere porém - e só isso explica que invoque também como pólo subordinado de sua equação o mito de Ulisses - que esse valor específico de nossa cultura seja uma espécie de coroamento de um processo de evolução universal, em que se passaria sucessivamente da natureza à cultura e da opacidade à luz ("consciência"). A versão do mito do indivíduo que nos apresenta assim é uma das muitas que compõem a cosmologia ociental. Não se trata apenas da versão a que G. Simmel chamou de "quantitativa" (e que se associa normalmente ao "liberalismo" clássico dos empiristas e dos iluministas): o indivíduo-cidadão e o indivíduo-calculador de seus meios e fins. Não se trata tampouco apenas do individualismo a que G. Simmel chamou de "qualitativo" e que associa à tradição romântica 
de ênfase na sigularidade, no desenvolvimento de cada indivíduo particular (sobretudo na linha da Bildung alemã, de que goethe é um epígono).

Trata-se de uma versão compósita, como são tão freqüentemente as grandes construções ideológicas do Ocidente desde o começo do século XIX. Ela herda o universalismo triunfalista do "liberalismo" e a ênfase singularizante do "romantismo", construindo uma espécie de evolucionismo culturalizante: essa caracterização do marxismo como versão alternativa da ideologia do "individualismo" não é, aliás, novidade. Outras análises já haviam avançado como o marxismo que privilegia do binômio original o pólo da "igualdade" - por oposição ao "liberalismo" que privilegiaria literalmente a "liberdade".

$\mathrm{O}$ apagamento da especificidade dos sonhos de cada cultura humana face aos nossos (e faustianos) é o primeiro preço a pagar nesse processo. Todos os outros humanos passam a constituir obtusas prefigurações da nossa forma de ser humano: outros tantos macacos de cuja anatomia é a nossa chave. A própria cultura grega, com sua identidade ambígua de mesma e outra, era figura no texto de Melo Filho como a aurora luminosa do Ocidente (na imagem romântica do "dia em que caíram as escaras dos olhos do Homem"), ora figura como o lugar da opacidade de um Ulisses que não soube ser Fausto, que se ateve à "conservação da vida" e não percebeu que seria necessário "sempre desejar", "passar por cima de, saltando".

O segundo preço a pagar é o de voltar a virar de cabeça para baixo a pobre história, transformando o desejado materialismo em uma metafísica - que era aliás, por motivos diferentes, o cerne da crítica de Goethe e dos demais românticos ao racionalismo iluminista: uma história que é a lenta a progressiva afirmação de um único homem, pleno de si mesmo, da autonomia do indivíduo pela razão consciente face aos constrangimentos da necessidade (natural e social). Vontade, verdade e interioridade - uma tríade que tenho proposto como chave da especificidade concreta dos valores da cultura ocidental voltam a ser figuras transcendentes a se afirmarem rumo à apoteose final.

O terceiro preço a pagar - e esse é mais lamentável, porque é mais concreto e imediato -é a insubsistência da análise, que nos apresenta o autor, do importante texto do Relatório Final da $8^{a}$ Conferência Nacional de Saúde. O que poderia ser uma esclarecedora interpretação da complexa negociação social que resultou nessa curiosa e vital peça histórica a ideológica - cheia de sonhos (valores) e contradições entre os sonhos (valores) -, acaba sendo uma simples e frustrante mensuração pelo cânone metafísico de um sonho específico: o de Fausto, relido em Budapeste na segunda metade do século XX.

\section{Maria Helena Machado \\ Departamento de Administração \\ e Planejamento em Saúde \\ Escola Nacional de Saúde Pública}

\section{Discutindo a Subjetividade da Saúde Pública}

O texto do Djalma é um exercício de prazer e uma renovação nos espíritos da saúde pública, per vezes tão conservadora e pouco aberta a inovações teóricas e metodológicas. Este texto representa esta possibilidade. Merecido prêmio.

Minha contribuição ao debate centra-se na discussão sobre a "subjetividade" do indivíduo que atua e produz Saúde Pública.

Falar sobre subjetividade não é uma tarefa fácil. Talvez impossível. Como diz Sartre, é necessário ultrapassarmos a insuperável opacidade da experiência vivida para saberrnos o que é o sujeito - se é que é algo - quem é o sujeito e, afinal, o que constitui a subjetividade.

Subjetividade diz respeito à rede de significados que circunscreve o sujeito, e, até certo ponto, determina-o. Por outro lado, a subjetividade afirma-se mais realisticamente em motivações não-adstritas aos enquadramentos da Razão em que o Iluminismo operou suas teses sobre o sujeito. Diríamos que o sujeito, inserido numa dada realidade social, compõe-se essencialmente de crenças e desejos.

A noção de sujeito passa essencialmente por dois eixos fundamentais.

O primeiro de tradição platônica define o sujeito como aquilo que se fala ou atribuem qualidades. Nestes termos o sujeito pode ser entendido por três dimensões: a) como a natureza que compõe uma coisa; b) como a forma da mesma; c) ou a união da matéria com a forma. $\mathrm{O}$ que importa é que, o sujeito nesses termos é o objeto 
real ao qual são inerentes ou se referem as determinações predicáveis.

$\mathrm{O}$ segundo de origem kantiana como eu ou consciência ou capacidade de iniciativa, coloca como central o eu penso, a consciência determinando toda a atividade cognitiva. A assertiva cartesiana que coloca o homem pensante como centro de sua existëncia - Penso, Logo Existo é o eixo fundamental das idéias contidas no sujeito kantiano.

Reconhecidamente Marx promove a ruptura no pensamento ocidental sobre o homem e sua relação com a natureza. O homem marxiano é inseparável da natureza, buscando sempre uma relação de complementaridade. Assim afirma Marx, "a produção de idéias, de representações e da consciência está em primeiro ligar direta e intimamente ligada à atividade material dos homens; é a linguagem da vida real".

No entanto, o homem contemporâneo é dotado de uma carga brutal de individualismo, marcada pela noção sujeito/consumidor, que tem a ilusão de ser único, individual com vontades e desejos próprios. O individualismo é um valor primordial das sociedades modernas. Creio eu, que esta dimensão radicalmente presente no nosso cotidiano foi negligenciada no texto de Djalma. Perguntaria-lhe: como pensar o homem coletivo, desenvolvendo trabalho coletivo numa sociedade marcada pelo individualismo, pela individualidade e pela competição? Buscando um diálogo provocativo, não poderíamos dizer que a Saúde Pública não deriva e se sustenta num acordo cartesiano, onde o pensar já pressupõe o agir e o fazer? O messianismo sanitarista, característica da área, não é um forte indício do que afirmamos acima? Sendo assim, como pensar o sujeito-sanitarista nos moldes apontados por Djalma?

Seguindo as idéias de Dumont, Guattari, Buadrillard e outros, as noções de subjetividade e sujeito, no mundo pós-moderno, obedecem, pois, a estratégias de dominação das formações de poder típicas do capitalismo moderno. Conferir a ilusão da autonomia do sujeito individuado, enquanto a cena política real é afastada do controle destes mesmos sujeitos. A assertiva cartesiana Penso, Logo Existo, é a expressão teórica desta colagem sujeito/indi- víduo, as duas instâncias da existência humana, atuando como se fosse uma só.

Por fim, gostaria de levantar uma questão que considero questão-chave para o mundo da Saúde Pública e que precisa ser desvendada: qual seria a subjetividade do homem de Saúde Pública? Teriam os praticantes desta área de conhecimento uma subjetividade inerente ao seu trabalho coletivo, dotado de idéias e ideais coletivistas?

Como repensar os desafios de Ulisses e Fausto, tomando a saúde, o indivíduo e a história como categorias-chave para o entendimento da Saúde Pública?

\section{Nísia Trindade Lima \\ Marcos Chor Maio \\ Casa de Oswaldo Cruz \\ Fundação Oswaldo Cruz}

\section{Saúde, Indivíduo e Modernidade}

O artigo de Djalma Agripino de Melo Filho tem o grande mérito de suscitar o debate sobre um tema da maior relevância: a relação entre as concepções de saúde e a problemática do indivíduo na modemidade. Num universo em que o discurso acadêmico encontra-se, com freqüência, divorciado das controvérsias e dilemas presentes na prática dos atores sociais, tentativas de estabelecer uma interpretação do ideário do movimento sanitarista, à luz dos grandes temas do pensamento ocidental contemporâneo, deveria merecer a boa acolhida de todos os que acreditam no papel das ciências sociais na reflexão teórica e na elaboração de propostas para a área de saúde. $\mathrm{O}$ artigo caminha, no entanto, em direção contrária àquela anunciada pelo autor, cabendo aqui reproduzir a advertência de Mefistófeles: "Meu amigo, toda teoria é seca, e a preciosa árvore da vida é florida" (Goethe, 1984).

Integrando o coro daqueles que vêm criticando as abordagens do marxismo estruturalista nas análises dos trabalhos sobre saúde, o autor propõe uma releitura das concepções de indivíduo e necessidades humanas na teoria marxista, enfatizando a importância da contribuição de Agnes Heller. Sua proposta consiste em demonstrar, à luz de tais premissas, a visão restrita de saúde 
e de indivíduo consignada no relatório da $8^{\mathrm{a}}$ Conferência Nacional de Saúde. Salta aos olhos a discrepância entre a atenção dedicada à explicitação dos "pressupostos teóricos" e a que se dirige para a análise da concepção de indivíduo prevalecente na $8^{\mathrm{a}}$ Conferência, resumindo-se as referências empíricas a pequenos trechos do $\mathrm{Re}$ latório Final. Este descompasso entre a formulação da teoria e a análise propriamente dita contrasta com as anunciadas intenções de diálogo, afirmadas ao longo do texto, que corroborariam a adesão ao assim chamado "marxismo-helleriano". Na verdade, o artigo padece do mesmo problema apontado na crítica que o autor faz ao marxismo de inspiração althusseriana: substitui-se a utilização de um conceito despido de historicidade - determinações estruturais (mesmo que "em última instância") - por conceitos aplicados igualmente de forma reificada, sem atenção para o contexto de sua produção e as possibilidades de uma aplicação enriquecedora. É curioso que as referências à abordagem de Agnes Heller não valorizem a dimensão propriamente histórica da obra da autora e excluam suas considerações a respeito dos três eixos que informariam a vida social na modernidade: a capitalização, a industrialização e a democratização, assim como eludam a importância atribuída pela autora aos valores democráticos, que implicariam novas formas de participação na vida pública.

O tema da vida pública não é abordado no artigo, mas tem uma importância acentuada nesta discussão. Um olhar mais atento sobre dois conceitos-chave presentes no texto pode ajudar a esclarecer melhor este ponto. O primeiro conceito é o de indivíduo - concebido como homem genérico. $\mathrm{O}$ caminho mais adequado para entender a posição do autor parece-nos ser o de partir de uma de suas referências centrais e indicadoras de uma ruptura das "necessidades existenciais" para as "necessidades humanas" - trata-se de Fausto e seu desejo de elevar-se da vida cotidiana.

As relações entre indivíduo e cotidianidade evocadas na obra de Goethe, expressam a angústia do indivíduo no cenário da modernidade. Alienação do homem de seu trabalho, de que nos fala tanto o "jovem" como o Marx da "maturidade científica"; contraste entre cultura subjetiva e cultura objetiva, com o quase sufocamento da individualidade, na crítica de George Simmel; desencantamento do mundo, nas palavras de Max Weber, enfim, são formas e diagnósticos diferenciados, mas que apresentam um ponto comum: o da objetivação da vida e do trabalho humano, com a perda da especificidade.

Diante deste cenário, várias alternativas são apontadas, todas problemáticas e não isentas de ambigüidades. Mas convém que nos detenhamos na expressão: elevar-se da vida cotidiana. Neste ponto, parece-nos importante lembrar as proximidades entre Goethe e Simmel. Ao discutir o contraste entre cultura subjetiva e cultura objetiva, segundo pressupostos claramente precursores daqueles presentes na Escola de Frankfurt, Simmel nos fala do caráter alienante da cultura objetiva que acompanharia o papel da economia monetária na sociedade moderna. Um diagnóstico evidentemente muito próximo ao do marxismo, mas acompanhado pela projeção de alternativas significativamente distintas. Tentando escapar de uma leitura unidimensional de quaisquer dos autores mencionados, cabe acentuar uma das possibilidades mais fortemente presentes na obra de Simmel. Nela, o elevar-se da vida cotidiana implica na preservação da integridade do indivíduo particular, capaz de, não apenas resistir, como também participar da banalidade do cotidiano, dele se distanciando e se elevando através de uma atitude muito próxima a de uma certa estetização e aristocratização da vida. A interação com o outro, a construção de uma cultura em bases comuns, e a participação na vida pública perdem, assim, a ênfase que revelam, entre outras, as análises de intelectuais como Karl Marx a Max Weber. O que sustentamos é que a principal questão do indivíduo na modemidade não é a de seu caráter enquanto "homem-genérico" ou "indivíduo particular", mas as possibilidades de construção da individualidade num processo interativo com a vida social e as demais individualidades em constituição, possibilidade aliás também indicada por Simmel em sua análise sobre as alternativas de construção do indivíduo. Trata-se de um processo relacional.

$\mathrm{O}$ conceito de necessidades humanas, tomado de Heller, da forma como é utilizado, pade- 
ce do mesmo grau de abstração. As contribuições mais significativas da autora consistem precisamente em, de um lado, recuperar certas "pistas" presentes na obra de Marx, enfatizando a dimensão simbólica das necessidades ou carências humanas e, de outro, ampliar o conceito através do recurso à temática weberiana do conflito de valores. No primeiro caso, a autora acentua a ênfase de Marx na tradição e no hábito social que orientariam a percepção das necessidades. Quanto à abordagem weberiana, Agnes Heller incorpora o diagnóstico do pluralismo dos valores sociais que caracterizariam o mundo moderno como base para sua análise do caráter conflitivo da percepção das necessidades humanas e da subjetividade. De qualquer forma, entendemos que os principais trabalhos da autora não autorizam uma visão tão normativa, a-histórica e, no limite, dogmática do conceito de necessidade humana.

A concepção, mais ampla ou mais restrita, do que sejam necessidades humanas, ou, em termos mais específicos, necessidades relacionadas à saúde, não pode ser examinada, sem referência à dinâmica de valores conflitivos que perpassam a vida social. Neste caso, o exemplo da $8^{\underline{a}}$ Conferência de Saúde dificilmente pode ser analisado, destituído de seu significado contextual, e das disputas teóricas e práticas ali presentes. A afirmação do Relatório Final da $8^{a}$ Conferência de que a saúde é "antes de tudo o resultado das formas de organização social da produção, as quais podem gerar grandes desigualdades nos níveis de vida", alvo principal da crítica do autor, apenas indica a influência de uma retórica marxista, nada esclarecendo sobre as posições envolvidas no debate. Ademais, o texto da $8^{a}$ Conferência é fruto de negociação entre movimentos sociais e agências estatais. Portanto, a expectativa de uma formulação "pura" de saúde e de indivíduo é no mínimo uma arrogância intelectual. A discussão perderia seu caráter diletante, se nos ajudasse a pensar na permanente tensão entre o individual e o coletivo a suas implicações na definição de prioridades que orientam as políticas setoriais.

Se, desde o início, afirmamos a pertinência de trazer ao debate as concepções de indivíduo prevalecentes na área de saúde, consi- deramos que o artigo não o promove enquanto um diálogo. Parece-nos uma tentativa de moldar a reflexão intelectual e, possivelmente, a prática social, a partir de um parâmetro dedutivo-normativo, tão carente de vida como a imagem de teoria que se apresenta na fala de Mefistófeles.

\section{Fermin Roland Schramm}

Departamento de Ciências Sociais

Escola Nacional de Saúde Pública

\section{A Dialética Ulisses-Fausto e o Desafio da Necessidade Radical}

"O Senhor Deus disse: 'Aqui está o homem, que pelo conhecimento do bem e do mal se tornou como um de nós. Agora é preciso que ele não estenda a mão para se apoderar também do fruto da árvore da vida, comendo do qual viva eternamente. O Senhor Deus expulsou-o do jardim do Éden [e] colocou, a oriente do jardim do Éden, querubins armados de espada famejante para guardar o caminho da árvore da vida",

(Gênesis, 3, 22-24)

Admitimos, com o autor, a pertinência da "dialética Ulisses-Fausto" para indicar "o desafio contemporâneo da Saúde Pública", consistindo, por um lado, no fato de uma "radicalização" das necessidades humanas constitutivas do bem-estar e, por outro, na prática capaz de operar uma dupla sutura epistemológica: a) a do cibernético Ulisses que simboliza a reforma da norma "natural" do humano pela técnica a que permite, portanto, resistir à regressão indicada pelo canto das sereias; b) a do político Fausto que apreende de Mefistófeles o jogo dos possíveis que define a arte da vida, inscrita necessariamente num contexto social a histórico, na ordem simbólica.

Desta forma podemos encarar a Aufhebung - o "passar por cima" das leis naturais do "animal" humano pela entrada na ordem sapiens que caracteriza a humanitude do humano -, relacionando-a com o tema das necessidades.

Mas a palavra Aufhebung implica dois tipos de operações, em princípio logicamente sucessi- 
vas: "levantar" e "ultrapassar", sendo que a segunda é conclusiva, pois implica a saída de uma norma paradigmática pela construção de outra. Assim sendo, o primeiro sentido de Aufhebung indica "levantamento" e "sustentação", logo as operações de distinguir, classificar e hierarquizar necessidades, como condição, logicamente necessária, para poder, em seguida, "radicalizá-las"; mas indica também uma operação de "conservação", de "retenção", a fim de não perder os nexos conceituais e histórico-sociais.

Ao dizer respeito tanto ao "inovar" como ao "conservar", a Aufhebung indica, portanto, uma duplicidade estrutural - apontada indiretamente pelo autor quando lembra os dois sentidos que se inscrevem na palavra salute - "conservar a vida"; "passar por cima, saltando" ou "ultrapassar". No entanto, existem ainda outros sentidos da palavra que se perdem nas suas origens indo-européias: o de "salvação" (mantido pela linguagem da teologia) e o de "saudação" (conservada em línguas como o italiano). Assim, a sabedoria da língua indica algo que perpassa o imaginário das épocas a respeito daquilo que tem a ver com a experiência da precariedade e da finitude da condição humana pós-edênica.

O caminho, aparentemente mais simples, de operar este "levantamento" foi através da distinção entre necessidades para a mera sobrevivência, tidas como "primárias" ou "naturais", e aquelas "secundárias" que qualificaram o bem/ bom viver e a norma especificamente humana (a "humanitude" do humano); em suma, entre a sobrevida e a qualidade de vida, distinção que o autor quer "ultrapassar", dialogando com a teoria das necessidades da Escola de Budapest.

A teoria das necessidades da Escola de Budapest se propunha em "passar por cima" da leitura redutora, anti-humanista e anti-historicista, feita pelo estruturalismo althusseriano, distinguindo entre necessidades "existenciais" (referidas à mera autoconservação do homem particular) e necessidades "propriamente humanas" - referidas ao "indivíduo", cuja qualidade de vida encontrar-se-ia necessariamente vinculada à qualidade de vida dos demais indivíduos, "determinadas" social e historicamente e não-redutíveis a "necessidades humanas alienadas" sintetizáveis pelo "possuir". O autor pergunta-se, então, de que maneira esta concepção de necessidades "propriamente humanas" possa ser aproveitada para se pensar "ra- dicalmente" a dialética entre o "primário" e o "secundário" no que diz respeito à situação sanitária concreta no Brasil; e detecta dois tipos de falhas no Relatório da $8^{\mathrm{a}}$ Conferência Nacional de Saúde: a) a subsunção da efetiva dialética entre os dois tipos de necessidades a meras necessidades quantitativas e existenciais, portanto "primárias"; b) a referência de suas propostas de reforma ao homem-particular, ao invés do indivíduo, e isso contradizendo paradoxalmente as declarações pragramáticas do documento sobre o "desenvolvimento pleno do ser humano em sua individualidade" (que retoma o preâmbulo da Constituição da Organização Mundial da Saúde de 1946: o completo bem-estar físico, psíquico e social).

Assim, o duplo sentido da palavra Aufhebung nos remete para um fundo cego da palavra necessidade; em particular, se pensarmos em termos da "necessidade radical".

Este fundo sem fundo encontra-se escondido na sentença tida como o texto mais antigo do pensamento ocidental: o fragmento de Anaximandro que nos fala de uma lei de necessidade. Para a epistemologia de Anaximandro, o "princípio" (arché) de todas as coisas é o "indeterminado" ou "ilimitado" (apeiron) que deve ser separado dos quatro elementos primordiais (fogo, ar, água e terra), pois estes, hostis entre si, acabariam por destruir o próprio apeiron enquanto princípio gerador de tudo aquilo que existe. Mas, no que nos concerne aqui, o fragmento de Anaximandro diz algo de extrema importância sobre o conceito de necessidade, pois, para o sábio Anaximandro, na passagem para a existência, as coisas são submetidas à destruição "conforme necessidade" (katá tó Kreón), infligindo umas às outras "a penalidade da sua injustiça conforme a ordem do tempo" (Diets-Kranz, 1966). A condição do que existe, inclusive a condição humana, é de estar submetido à lei da necessidade e à lei do tempo, algo inevitável, destinal. Como sintetizará, muito depois, Ortega y Gasset, a vida para o humano é uma "realidade radical" inelutável. Ora - como afirma Severino (1980) - durante toda a história do Ocidente, a necessidade nunca foi pensada na sua radicalidade e todas as palavras (sinônimos, paráfrases) que tentaram dizer algo a seu respeito, obscureceram seu sentido originário, inominável, tomando-se palavras doentes.

É por isso, acredito, que deveríamos radicalizar o conceito de necessidade, no duplo sentido 
de: a) aprofundar o seu fundo sem fundo; b) detectar a sua parte destinal. Aprofundar "até a raiz", até às palavras primordiais que dizem respeito ao espanto e à revolta perante a finitude $\mathrm{e}$ a precariedade, à lei de necessidade simbolizada pelo mito da expulsão do Éden e que marca a condição ontológica de cada humano e de todos os humanos, radicalmente dividida entre um saber distinguir entre o bem e o mal e um não saber como sobreviver para além de determinados limites, independentemente da sua "evolução" graças ao saber-fazer da tecnociência.

Em conclusão, ao ser enunciada, a "necessidade radical" esconde um sentido inaudito que parece resistir à liberdade e à história, à autonomia humana, que, pela lei de necessidade, encontra-se destinalmente vinculada à heteronomia, deixando aparecer uma impossível Aufhebung, pois os querubins armados do mito bíblico guardam o caminho da árvore da vida que, para todo ser humano, é também a árvore da precariedade e da finitude, metáfora de lei de necessidade.

Podemos, portanto, perguntar se a queixa contra as supostas "reduções" acarretadas pela distinção entre necessidades "primárias" e "secundárias", entre necessidades da sobrevida e da qualidade da vida, não remeteriam, em última instância, para uma revolta perante o espanto frente à condi- ção humana submetida à lei da necessidade, conforme a ordem do tempo e da destruição, recalcada pelos Ulisses do nosso tempo que substituíram à "barreira cerática" as construções da realidade virtual, vindo a ocupar, desta forma, o lugar do avestruz que, enquanto esconde a cara no buraco, esquece de estar sendo depenado, sem piedade, no lugar que mais mostra a sua fragilidade? A comicida de desta imagem - "imortalizada" pelo psicanalista Jacques Lacan e retomada, recentemente, pelo epidemiologista Luis David Castiel - não impede que ela revele o fato de uma tragédia que se consome no dia-a-dia dos humanos, submetidos à lei de necessidade simbolizada pelo mito da expulsão do Éden, isto é, desde que Adão se tomou Homo sapiens, cujas "pretensões em ocupar a terra, e a reinar sobre ela e aquilo que nela se encontra, se concretizaram cada vez mais" (Allan, 1991: 11). Ou será que a perdição é só do outro?

\section{REFERÊNCIAS BIBLIOGRÁFICAS}

ATLAN, H., 1991. Tout Non Peut-Ettre. Paris: Ed. Du Seuil.

DIELS-KRANZ,1966. Die Fragmente der Vorsokratiker. 121 ed., Berlin.

SEVERINO, E., 1980. Destino della Necessitá. Milano: Adelphi.

\section{O AUTOR RESPONDE / THE AUTHOR REPLY}

1. As reflexões do professor José Ricardo de C. M. Ayres nos impelem a destacar, devido à exigüidade de espaço, pelo menos uma delas: na busca pelo Verdadeiro e pelo Bem, como conciliar a permanência e a efemeridade da própria existência humana? Weber diz que o homem consegue o possível porque busca o impossível. Caminharemos nesse sentido. Se, ao criticarmos o "escândalo da filosofia" (o positivismo), propomos a união da ciência com o “deve-ser", não estaríamos nós, após rejeitar pela enésima vez as facilidades do relativismo pós-moderno, desejando, agora, uma ética do "é"? O "mundo das idéias" de Platão ou o "Eu sou a verdade" de Cristo são exemplos de solução anistórica para o problema. A tentativa do marxismo de historicizar o ponto de apoio, através da "missão" do proletariado mostrou-se, empírica e filosoficamente, problemática: a referida classe resolveu desobedecer as "leis" da história, não vindo a romper com o particular. "E agora, José?" Como ser permanente sem ser eterno (anistórico)? Como ser efêmero sem ser relativista? Fiel à tradição da filosofia antiga, Heller em sua teoria sobre o valor verdadeiro propõe a criação de um silogismo cuja premissa maior, composta pelos ideais de valor (liberdade, felicidade, personalidade, vida humana, humanidade e igualdade), é histórica e universalmente válida, ou melhor, tornou-se universal na história porque assim houve condições e, de igual modo, porque desejaram os homens. Portanto, diz Heller (1983), "se um valor é relacionado com um ideal de valor a revela-se entre os dois uma contradição, o valor [em questão] não é verdadeiro". Sendo 
assim, a saúde seria também um valor verdadeiro. Cabe ainda ressaltar que esses ideais apesar de serem válidos por mais algumas décadas, ou mesmo séculos, isso não nos autoriza a eternizá-los como no desejo de Utnapishtim, embora o professor José Ricardo não nos tenha revelado se o sábio babilônico consseguiu o seu intento. Finalizando esta reflexão, cabe sublinhar que "estamos confinados a uma Conjuntividade junto com os mortais corn quem compartilhamos nossa vida. Com efeito, o poço de nosso passado é muito profundo a vastíssima é nossa responsabilidade. Temos, contudo uma única vida. Assim sendo, não tenha pressa Capitão Para-Frente! Qualquer pressa só apressa nossa morte. (...) Godot não virá, mas nós certamente partiremos. (...) Se podemos víver uma vida digna - por que não tentar?" (Heller, 1993: 395).

2. Em relação à contribuição da professora Maria Cecilia de Souza Minayo, gostaríamos de destacar a sua interessante compreensão da "barreira cerácea": os marinheiros de Ulisses não poderiam se comunicar! O que seria discutido na "comunidade ideal de comunicação" de Apel se acreditamos que os paradigmas são incomensuráveis? se concebemos os valores como sendo deduzidos dos interesses? se compreendemos o socialismo como a ausência de contlitos? se tomamos como equivalentes a dóxa e a epistéme? Talvez seja necessário repensar os referidos marcos, como deseja Minayo, antes que o capitalismo torne os homers "iguais", pois, segundo Heller, a utopia de uma sociedade inteiramente autogovernada carrega consigo o dever de propiciar o pluralismo das formas de vida, pois os "seres humanos só podem ser socialmente iguais se forem desiguais em gostos, inclinações, desejos, talentos e interesses". Para haver comunicação, é necessário que os homens partam do princípio que é possível convencerem e serem convencidos sobre uma determinada questão dentro de uma discussão racional: os valores não são irracionais, existem, como foi visto no comentário à contribuição do professor José Ricardo, assim como o conhecimento, valores verdadeiros. A liberdade, mesmo sendo o sumo-bem da filosofia burguesa, ao ser universalizada, não é mais um valor de uma classe particular, mas sim de toda humanidade. Outro marco a ser abandonado é a banalidade pós-moderna que não se esforça em diferenciar, como desejava a filosofia antiga, a dóxa da epistéme onde estariam unidos o Verdadeiro, o Bem e o Belo. Se não há diferença, o que discutir, então? A atomização da particularidade quando universalizada, possibilita que surjam, enquanto sinédoques, um anti-Ulisses e um anti-Fausto: neste caso, seria o homem-particular, e não as sereias, que "negaria" o indivíduo.

3. As instigantes observações feitas pelo professor Luiz Fernando D. Duarte nos impelem ao exercício, previsto na "situação de fala ideal", da discordância. Inicialmente, nos moldes de uma certa tradição tão comum às "esquerdas", a argumentação visa a "diagnosticar" nossa filiação: marxista-metafísica? idealista? adepto do "evolucionismo culturalizante", síntese do "universalismo triunfalista do 'liberalismo' com o 'romantismo'"? Felizmente, essa tradição está sendo abandonada, pois muitas vezes ratifica o "dogma" kuhniano da incomensurabilidade dos paradigmas, reafirmando, como diz Minayo, a nossa "incompetência de promover a isonomia das forças em oposição". Como exemplos, Apel, Habermas e Heller contrapõem a racionalidade da "comunidade ideal de comunicação" à irracionalidade dos conflitos entre paradigmas. Passemos, pois, a refletir sobre as críticas. Se o nosso texto discute filosofia a história, acreditamos que ele não trata, pelo menos nos moldes tradicionais, de filosofia da história, pois faltam-lhe os pressupostos essenciais que a caracterizam. Em nenhum momento, defendemos uma teoria da evolução universal, uma teleologia histórica ou mesmo a existência de "leis" necessárias e independentes da vontade humana que impeliriam a transformação de Ulisses em Fausto. Falamos de possibilidade: um fato histórico pode ocorrer se houver condições para que ele ocorra, mas também se decidirem que ele possa ocorrer. Aí talvez resida nossa ruptura com os cânones da filosofia marxista da história. Não obstante, esse abandono não deve ser pretexto para a defesa de um relativismo culturalizante como propõe a primeira crítica. Existem valores que 
foram universalizados na história e relativizaram o argumento da "especificidade dos sonhos de cada cultura". A segunda crítica nos remete para um estado intermediário (segundo) sob a vigência da "lei" comtiana. Ela encontra-se tão distante do que diz o texto original que deve ser revista à luz das citações de Markus, que fogem do liberalismo e do estruturalismo, sobre a história. Os marxismos benjaminiano e blochiano também já foram considerados metafísicos. O rótulo de metafísico, ou melhor, de idealista não impediu Heller de fundar sua ética sobre a união de Kant com Marx. Em relação a última crítica, gostaríamos de dizer a "complexa negociação social" que permitiu a elaboração do referido Relatório em nada relativiza a hipótese central de nosso trabalho. Poderíamos, talvez, reescrevê-la da seguinte maneira: o Relatório Final da $8^{\underline{a}}$ Conferência Nacional de Saúde, apesar de..., visou ao homem-particular e não ao indivíduo.

4. Consideramos muito oportuno o registro da professora Maria Helena Machado sobre uma das (muitas) lacunas de nosso texto: a questão do individualismo na sociedade moderna. Se é verdade que a emergência da sociedade burguesa criou condições para a emergência da individualidade; é também verdade que criou consideráveis obstáculos, inclusive a crença de que a satisfação dos interesses privados seria o motor para o progresso. Esse recuo para o espaço privado é característico da modernidade. Buscando a "segurança", o indivíduo, assinala Heller, experimenta o desespero, a solidão e a infelicidade. É necessário resgatar duplamente a idéia de progresso, não como uma "necessidade histórica", mas como um valor, e a dimensão pública do espaço. Em princípio, se aderirmos às filosofias de Heidegger a Nietzsche, identificadas com o "retrocesso histórico", mas como fizeram os estruturalistas franceses, também não nos libertaremos do messianismo das filosofias marxista e hegeliana da história, adeptas de um "progresso universal". No primeiro caso, chegaríamos ao Inferno e no segundo, ao Paraíso. Concordando com Collingwood e Heller, partimos de uma posição que nega ambas as saídas: a análise de cada situação permitirá avaliar se há progresso, entendido por "ganhos sem perdas correspondentes", ou retrocesso, compreendido por "perdas sem ganhos correspondentes". Tornando ético o pensamento de Marx, que assevera que transformando o mundo, os homens se transformam a si mesmos, Heller diz que "não podemos transformar o mundo se, ao mesmo tempo, não nos transformarmos nós mesmos". Tanto o socialismo como a "utopia sanitária" devem ser compreendidos enquanto valores e como tais a sua racionalidade independe da realização do fim. Essa posição compartilha de uma ética estóico-epicurista, reafirmada por Heller, que empreende "ações racionais de valor sem importar-se com o sucesso ou o fracasso delas. A derrota é sofrida e o sucesso é gozado, mas em ambos os casos, no sofrimento ou na alegria, tem de prevalecer sempre a mesma coragem e decisão".

5. Em relação aos comentários dos professores Nísia Trindade Lima e Marcos Chor Maio, queremos destacar três aspectos que nos parecem importantes. O primeiro refere-se à contribuição de Simmel sobre o indivíduo, sem dúvida fundamental para o debate. Concordamos que a "elevação" do homem-particular à universalidade, afirmando o valor "indivíduo", é um processo relacional e interativo da "vida social e as demais individualidades em constituição", pois esse valor somente se expressa em sociedade, ou, em termos utópico-racionais, em comunidade. Não se trata de resgatar, romanticamente, as comunidades naturais pré-burguesas nas quais os homens ao nascerem pertenciam a elas naturalmente; muito pelo contrário, no caso moderno é necessária, a fim de construí-las, uma tomada de decisão, de forma consciente, por parte do homem. Reconhecemos que essa face do problema foi desconsiderada no nosso texto. O segundo é sobre a "discrepância" entre teoria e análise, consideramos que o nosso objetivo, que também "salta aos olhos”, não visou à realização de uma hermenêutica do Relatório como um todo. A análise dos excertos, advindos da parte conceitual do referido documento, pareceu-nos contribuir para o não falseamento da hipótese. Ou, também seria bom indagar, o restante "desconsiderado" do Relatório ajudaria a refutá-la, ou pelo 
menos abandoná-la? A crítica também não respondeu essa questão. O terceiro aspecto refere-se a alguns elementos fundamentais da obra helleriana. Foi salientada a influência de Marx e Weber sobre Heller, todavia Lima \& Maio esqueceram de assinalar que a ética helleriana é essencialmente kantiana, assim como a "sociologia formal" de Simmel. Ao contrário do que diz a crítica, pode-se constatar que a teoria helleriana dos valores, descrita em "A Filosofia Radical" e também presente em "Uma Teoria da História", pretende "moldar a reflexão intelectual e, possivelmente, a prática social, a partir de um parâmetro edutivo-normativo". A teoria proposta pela filósofa é histórica, pois os ideais de valor (liberdade, humanidade, vida humana, igualdade, personalidade a felicidade) foram universalizados na própria história. A liberdade, por exemplo, é um valor de origem fundamentalmente burguesa, todavia essa particularidade foi rompida e tornou-se universal. Heller rejeita a concepção que admite ser o valor deduzido dos "conflitos de interesses" ou mesmo das necessidades. Existem afinidades, mas não necessariamente identificação, pois, se caso houvesse, os valores não poderiam ser universalizados, possibilidade que foi mostrada pela história. A sua teoria não se "ancora" no proletariado para assegurar a sua verdade, pois os interesses de classe não vem rompendo, empiricamente, com a dimensão do particular o que seria necessário para garantir a referida verdade. A discussão filosófica sobre valores partiria de uma unidade "sem interesses" que seria a humanidade. Por fim, de modo irônico, a vida também encontra-se na premissa maior do argumento dedutivo, a partir do qual seria avaliada a verdade dos outros valores. Talvez, neste caso, Mefistófeles não tenha razão.

6. O professor Fermin Roland Schramm enriquece sobremodo o filosofar sobre a dialética Ulisses-Fausto, ou, em outras palavras, sobre a síntese das necessidades relativas à sobrevida e à qualidade de vida, quando propõe radicalizar o próprio conceito de necessidade. Acreditamos que ao pensar sobre a "lei da necessidade", Schramm nos convida a buscar respostas para a seguinte indagação: é possível, do ponto de vista empírico e teórico, ratificar a dialética histórica sem a âncora da filosofia marxista da história, já que os pressupostos dessa última (teleologia, futuro deduzido do passado, determinismo das "leis históricas", evolucionismo etc.) foram recusados no nosso texto? Deslocando a causa finalis da história para as ações humanas na própria história talvez possa ser um ponto de partida: os grupos identificados com as chamadas necessidades radicais poderiam "negar" uma situação histórica (porque decidiram fazer isto e não porque existe uma necessidade infra-histórica que os obrigaria a fazê-lo).

Se isto de certa forma restitui a autonomia das ações humanas, por outro lado não afasta a "revolta perante o espanto frente à lei da necessidade, conforme a ordem do tempo e da destruição...".

O próprio Marx, ao refletir sobre a antinomia, identifica a pré-história com o reino da necessidade e a verdadeira história (comunismo) com o reino da liberdade. Segundo ele, a própria morte somente na aparência nega a unidade entre o gênero e o indivíduo. Para Heller a finitude humana, mesmo inexorável, já é marcadamente, por ser humana, diferente: "Só o homem é mortal, porque só ele sabe que um dia já não estará aqui”. Retornando à metáfora proposta por Schramm, poderemos imaginar um Deus espinosiano que, ao "expulsar" (libertar) o homem dos jardins do Éden, poderia ter parafraseado Drummond dizendo: "Vai", Adão! "ser gauche na vida".

Finalmente, queremos agradecer à Direção da Escola Nacional de Saúde Pública pela criação do Prêmio Joaquim Alberto Cardoso de Melo, estimulando, dessa forma, a reflexão sobre os problemas e os desafios contemporâneos da Saúde Pública, ao Editor dos Cadernos de Saúde Pública que permitiu que o debate se tornasse público e aos professores que contribuíram para o enriquecimento do debate. Dedicamos, ainda, nosso esforço intelectual à luta pela construção da Escola de Saúde Pública de Pernambuco. 